\title{
A Soft Computing Framework to Support Consumers in Obtaining Sustainable Appliances from the Market
}

\author{
Ricardo Santos ${ }^{1,2, *(\mathbb{D})}$, António Abreu ${ }^{1,3}{ }^{\oplus}$, José Soares ${ }^{4}$, Fernanda Mendes ${ }^{5}$ and \\ João M.F. Calado 1,6 (D) \\ 1 Instituto Superior de Engenharia de Lisboa (ISEL), Instituto Politécnico de Lisboa, 1959-007 Lisboa, Portugal; \\ ajfa@dem.isel.ipl.pt (A.A.); jcalado@dem.isel.ipl.pt (J.M.F.C.) \\ 2 GOVCOPP-Universidade de Aveiro, 3810-193 Aveiro, Portugal \\ 3 CTS Uninova, Faculdade de Ciências e Tecnologia, Universidade Nova de Lisboa, 2829-516 Lisboa, Portugal \\ 4 ADVANCE-Instituto Superior de Economia e Gestão (ISEG), Universidade de Lisboa, 1200-109 Lisboa, \\ Portugal; josesoares@iseg.ulisboa.pt \\ 5 Universidade Europeia, 1500-210 Lisboa, Portugal; fernanda.mendes6@gmail.com \\ 6 IDMEC-IST, Universidade de Lisboa, 1049-001 Lisboa, Portugal \\ * Correspondence: ricardosimoessantos84@ua.pt
}

Received: 1 April 2020; Accepted: 28 April 2020; Published: 4 May 2020

\begin{abstract}
Currently, sustainability is considered a priority by society, with the household appliances being one of the economic sectors involved in achieving sustainability. However, the existence of several issues (e.g., energy and water consumption, reliability, initial cost, and illuminance, among others) together with the diversity of brands and models on the market, make the consumer's decisions regarding sustainable options difficult, according to their concerns and related to each sustainability dimension (economic, environmental, and social). By combining evolutionary algorithms (EA) with multicriteria techniques, it is possible to achieve sustainable solutions for the consumer based on their requirements. In this paper, a method is presented to support the consumer by obtaining a set of sustainable household appliances on the market that suit their preferences, concerns, and needs. By using a case study to apply the approach developed here, a set of sustainable appliances from the market is obtained, where several benefits are achieved (e.g., energy and water consumption savings, avoidance of $\mathrm{CO}_{2}$ emissions) during the lifecycle of each appliance, chosen from the appliance's industry.
\end{abstract}

Keywords: sustainability; energy efficiency; cyberphysical system; decision support systems; lifecycle cost analysis (LCCA); multi-attribute value theory (MAVT); multi-objective optimization; soft computing; evolutionary algorithm

\section{Introduction}

According to [1-4], the consumption of energy should be reduced in order to achieve sustainability. Approximately $38 \%$ of the final energy consumption is related to the building sector, and from that percentage, approximately $18 \%$ is related to the residential sector [4], which thereby represents a relevant sector for which to achieve sustainability.

With regard to household appliances, some measures have been made not only in Europe but in other world regions as well, in order to promote sustainability in this sector.

One of such measures, adopted in this context, is mandatory labeling [5-8], which allows informing the consumers about information related to each electrical appliance, such as heat capacity (air conditioner), water and energy consumption (dryer machine), and initial investment (lighting), among others. The goal of such a measure is to adjust each available solution to the consumer's needs [6-8]. 
Besides energy labeling, there are also eco-design policies, with both acting as essential tools to drive the shift from a "linear economy" to a more "circular" one that also promotes sustainable development $[9,10]$.

Furthermore, and by including eco-design and energy labeling measures, the European Union has changed the way that our products are designed, bringing substantial reductions in terms of greenhouse gas (GHG) emissions and the corresponding consumption costs $[4,5]$.

By 2020, and based on [9], the European Commission estimates that the energy consumption costs for each household in Europe will be approximately reduced by $€ 300$ per year, due to the adoption of such policies, with GHG emissions also seeing a reduction of approximately 319 megatons of $\mathrm{CO}_{2}$ (equivalent) per year.

According to some studies, which include the EU's recommendations, increasing the durability, reparability, and recyclability of the products and, in particular, electrical appliances, represents an opportunity to improve eco-design and energy labeling measures with respect to the promotion of a circular economy [3-6].

Although sustainability is a goal to be achieved, the circular economy is a way to achieve such an end, therefore being a road map that should lead society to reach sustainability [4]. However, some studies argue that the circular economy will not be enough to achieve sustainability $[4,8]$, since it only focuses on technological progress to solve economic and environmental problems, making it a "weaker" sustainability approach $[9,10]$.

On the other hand, the rise of new developments resulting from the combination of information technologies with decision support systems, together with new business models of product service systems as well, could also help to satisfy the need for cultural change in order to reach a "stronger" sustainability approach $[5,8,9]$.

The circular economy is a means to achieve sustainability since it helps (directly and indirectly) meeting targets of the Sustainable Development Goals defined by the United Nations [11].

As mentioned before, energy labeling policies, as well as eco-design, are essential tools to drive the shift to a circular economy [12].

Several studies regarding the circular economy and sustainable development issues have been developed by considering several contexts (e.g., market surveillance of resource efficiency [9], energy renewables [13], circular economy performance indicators [12,13]).

In recent years, several entities, including governments, associations, and manufactures, have also used measures in an attempt to sensitize the population to the problem of energy efficiency in the residential sector [14-16].

Despite the existence of such measures, it becomes difficult for a decision-agent (consumer) to acquire the best solution adjusted to its needs and preferences, given the diversity of options from the market (brands and models) as well as the diversity of the appliance's own features [14-16].

In this sense, the use of multicriteria techniques can support the consumer in making sustainable choices that not only address the consumer's preferences, but also their concerns and needs according to three dimensions of sustainability, namely economic, environmental, and social wellbeing. In addition, the use of multi-attribute value theory (MAVT), combined with optimization techniques, could also help to define the consumer's decision space and the corresponding objective functions in order to maximize the three objective functions mentioned above.

Based on previous work, evolutionary algorithms (EA) and, more specifically, the non-dominated sorting genetic algorithm II (NSGAII) have been successfully deployed to solve optimization problems with more efficiency than other methods by providing different and feasible solutions, given their stochastic nature [17-22].

Therefore, this work presents an integrated method, based on NSGAII and MAVT, with the aim of supporting the decision-agent (consumer) in finding sustainable solutions from the market based on different needs and concerns. 
The method proposed here can also provide other sustainable (optimal) and alternative solutions to the consumer.

The applicability of the proposed approach will be demonstrated through a case study, where a set of sustainable (and alternative) solutions is obtained, given the consumer's issues, which include preferences and needs, on behalf of their economic, social, and environmental wellbeing.

The presented approach also includes economic (e.g., budget), social (e.g., minimum value of air conditioner heat capacity), and environmental (e.g., $\mathrm{CO}_{2}$ emissions) constraints, related to each energy service (household appliance) considered in this work.

This paper is organized as follows: Section 2 contains the literature review and the paper's contribution. Section 3 contains the research method used, namely the adopted criteria regarding the three dimensions considered in this approach, the problem formulation, the strengths, weaknesses, and limitations of the work, and ending with a brief presentation of NSGAII. Section 4 presents and discusses the obtained results. Section 5 presents the conclusions and further work.

\section{Literature Review and Paper's Contribution}

\subsection{Literature Review}

Methods based on simulation (e.g., [23]) are commonly applied to simulate a restricted set of alternatives.

Other approaches are mainly economic, allowing consumers therefore to acquire the highest energy savings for the same initial investment (e.g., $[17,18])$, while others exploit issues based on the building's thermal performance by using evolutionary algorithms to optimize the building's parameters, thereby achieving GHG emission savings, among other perceived benefits (e.g., [22,23]), with some of them being also integrated with technologies (e.g., [24,25])

However, such approaches can be considered somehow limited because they do not consider other important issues (e.g., environment, energy labeling, and consumer's satisfaction, among others) to achieve solutions suitable for the consumer's needs. They also do not account for the criteria regarding each household appliance existing on the market, which can differ based on the number of household building occupants.

Presently, some works have created multicriteria decision-making (MCDM) approaches to support consumers with measures regarding buildings by accounting for energy efficiency and comfort in buildings (e.g., [6,26]), while other approaches were performed by ranking the different available options (e.g., [23]).

Some approaches promote sustainable measures by using the game theory model to maximize environmental and utility objectives with respect to the energy production sector (e.g., [21]), while other works promote sustainability measures by using fuzzy logic applied to the transportation sector while considering not only environmental issues (pollution), but also customer satisfaction (e.g., [21]).

In the literature, other MCDM models can be found as well as multiple-attribute value theory (MAVT) methods that allow combining optimization with multicriteria methods in order to obtain feasible solutions through according to a set of criteria (e.g., [18-20]).

However, these methods do not account for the different criteria regarding each household appliance, from the market, suitable for the consumer's needs.

Optimization methods based on metaheuristics have been also considered to solve energy problems by providing feasible solutions, such as genetic algorithms (GAs) (e.g., [20,22]) and particle swarm optimization (PSO) (e.g., [19,24]), among others.

However, such methods are not integrated as a combined approach to enable selection, from the market, of a set of sustainable appliances for the consumer (decision-agent) that are based on a set of criteria. 


\subsection{Paper's Contribution}

Based on the literature discussed above, there is a gap regarding sustainable measures for buildings, involving household appliances, that allow supporting a household consumer in choosing a set of sustainable solutions from the market.

Therefore, the main contribution of this paper is the design of an approach to support a consumer to identify sustainable options for household appliances that exist on the market that attends to their needs, as well as a set of requirements, namely:

(1) Maximization of a consumer's economic wellbeing (water and energy consumption savings, investment savings, etc.);

(2) Maximization of a consumer's social wellbeing through their preferences (e.g., design, quality perceived, noise, and number of functions, among others);

(3) Maximizing the consumer's environmental wellbeing (avoidance of $\mathrm{CO}_{2}$ emissions, water savings);

(4) Providing a methodology that allows obtaining several alternative sustainable solutions, which allow tackling some contingencies that eventually may occur (e.g., an out-of-stock electrical appliance initially recommended by the method).

In order to fulfill the previously identified gap, this work presents a decision support approach that provides the consumer (decision-agent) with a set of household appliances obtained from the market according to their preferences and needs.

The method presented here also promotes the circular economy by promoting sustainable options that exist on the market.

The presented approach also includes economic (e.g., budget), social (e.g., minimum value of air conditioner heat capacity), and environmental (e.g., $\mathrm{CO}_{2}$ ) restrictions related to each energy service (household appliance type) considered in this study.

\section{Material \& Research Method}

\subsection{Problem Statement and Case Study}

The problem presented in this work considers a household consumer (decision-agent) who wants to acquire different electrical appliances, existing in the market, for their household.

Thus, and regarding the case study used in this work, seven different energy services/electrical appliances to be acquired by the consumer were considered, namely dryer machine, lighting, air conditioner, dishwasher machine, electric oven, washing machine, and refrigerator.

The same consumer had a restricted budget of $€ 2500$, to acquire seven types of household appliances, with the goal of achieving a set of sustainable equipment that maximized their social, environment, and economic wellbeing according to a set of three relative importance weights, respectively $\omega_{A}$ (economics), $\omega_{B}$ (social), and $\omega_{C}$ (environment). In this case study, these were considered using values of $0.65,0.25$, and 0.1 , respectively.

In total, the building has four occupants. Given the consumer's intention to buy an air conditioner, the corresponding cooling and heating needs were calculated based on the corresponding room area (living room).

Regarding the remaining assumptions, they are presented on Table 1, with the emission factor obtained from [27], while the consumer's usage profile is presented on Table 2, based on a Portuguese study [7].

Such a profile was adopted and based on a typical consumer's profile, considering the work in [7] and regarding the use of each household appliance type to be acquired.

However, the consumer can also create their own usage profile based on their needs or using the profile shown in this work by default. 
Both set of assumptions shown on Tables 1 and 2, were considered when performing a lifecycle cost assessment (LCCA) related to each individual solution/appliance, which is described on next section.

Table 1. Emission factor and other assumptions considered in this work.

\begin{tabular}{cccc}
\hline Emission Factor $\left(\mathrm{gCO}_{2} / \mathbf{k W h}\right)$ & $\mathbf{6 7 5 . 0 0}$ & Discount Factor $(\mathbf{\%})$ & $\mathbf{7 . 0 0}$ \\
\hline Lifecycle (usage phase) $($ years $):$ & 10.00 & Annual Factor & 7.03 \\
Electrical Energy tariff $\left(\tau_{\text {Elect. }}\right)(€ / \mathrm{kWh})$ & 0.16 & Water tariff $\left(\tau_{\mathrm{H}_{2} \mathrm{O}}\right)\left(€ / \mathrm{m}^{3}\right)$ & 1.19 \\
\hline
\end{tabular}

Table 2. Consumer usage profile (considered).

\begin{tabular}{ccccc}
\hline \multirow{2}{*}{ Energy Service } & \multicolumn{4}{c}{ Hours } \\
\cline { 2 - 5 } & Day & Week & Month & Year \\
\hline Dryer machine & 1.5 & 4.0 & 15.0 & 183.0 \\
\hline Washing machine & 1.2 & 4.3 & 16.0 & 189.0 \\
\hline Fridge/freezer & 11.0 & 76.3 & 329.1 & 4007.0 \\
\hline Oven (electric) & 1.1 & 1.9 & 8.0 & 97.0 \\
\hline Dishwasher machine & 1.0 & 4.1 & 16.0 & 193.0 \\
\hline Air conditioning & 2.1 & 12.1 & 47.0 & 587.0 \\
\hline Lighting & 5.0 & 35.2 & 150.1 & 1823.0 \\
\hline Energy Service & & Usage Frequency & \\
\hline Dryer machine & 1 & Week & Month & Year \\
\hline Washing machine & 1 & 3 & 14 & 185 \\
\hline Fridge/freezer & 1 & 2 & 14 & 181 \\
\hline Oven (electric) & 1 & 6 & 28 & 359 \\
\hline Dishwasher machine & 1 & 2 & 7 & 94 \\
\hline Air conditioning & 1 & 3 & 14 & 189 \\
\hline Lighting & 1 & 4 & 22 & 276 \\
\hline
\end{tabular}

\subsection{Dataset}

Based on the data presented before, namely the consumer's profile presented in Table 2, as well as the remaining assumptions, it was some calculations were performed using an LCCA approach in order to achieve savings for each appliance, regarding energy and water consumption, for each appliance considered in the decision space (Figure 1). The lifecycle period was also considered in this study (10 years). This was done by using the consumer profile, as considered in Table 2, and by comparing the consumption from each candidate solution (regarding each energy service) with the corresponding less-efficient one in terms of energy consumption, considered here as a "standard solution".

Data from the appliance's market was also considered, such as initial investment, brand and model, power, and noise, among other appliance issues regarding each appliance, and based on the criteria, as presented in Table 3.

In Appendix $A$, the adopted attributes regarding each obtained solution are presented.

In Appendix B, the final attribute values based on MAVT are presented.

\subsection{Proposed Approach}

The method presented in this work has been designed to support a consumer who intends to purchase, from the market, a set of appliances for their household (Figure 1). 
This set is formed by individual solutions regarding each energy service to be acquired and is obtained from a group of candidate solutions previously selected using MAVT according to the consumer's preferences, needs and concerns, and regarding each sustainability dimension (Figure 1).

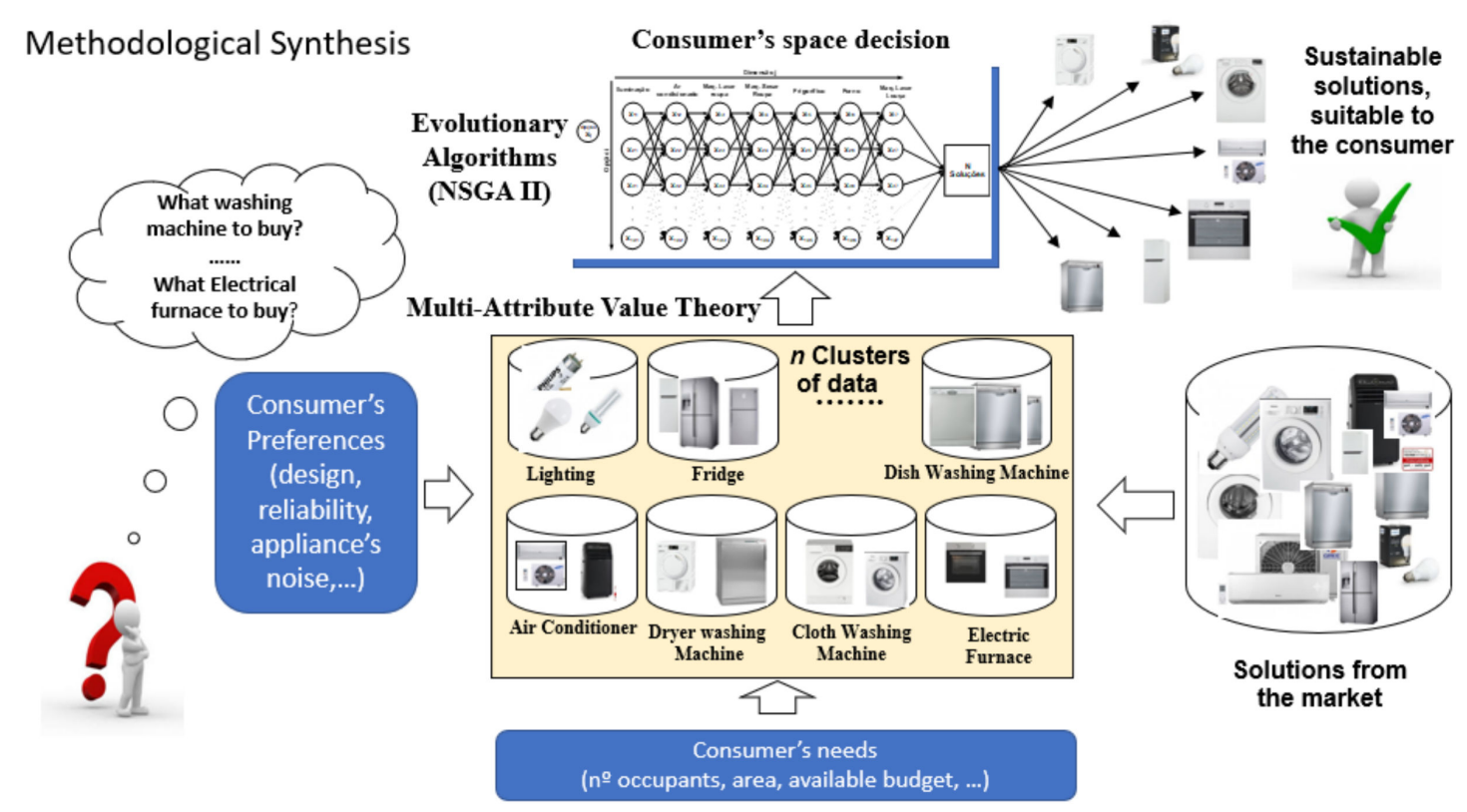

Figure 1. Proposed method.

Such an approach can be better described through a detailed view, as presented in Figure 2. The first phase starts with pre-selection of a set of potential solutions $\left(x_{i j}\right)$ from the market and based on specific criteria. Although the corresponding attributes/criteria remain the same, the corresponding values vary according to the number of occupants.

The adopted criteria used here allows for the pre-selection of household appliances available in the market, so the decision space can be reduced by considering only these options that are adjusted to the consumer needs as well as through increasing the efficiency of NSGAII by acquiring optimal and feasible solutions within less time.

According to Figure 2, the first stage starts with the pre-selection of a set of candidate solutions $\left(x_{i j}\right)$, existing in the market, which are based on specific criteria and according to the number of occupants of the building. Regarding the adopted criteria, it is the same, with the corresponding attribute' values varying based on the occupant number. An example of such criteria, considering the case studied in this work, is shown on Table 1.

Therefore, each candidate solution $\left(x_{i j}\right)$ is then considered as an option $i$ related to household appliance type $j$, to be bought from the market by the consumer.

By considering a consumer's profile, (e.g., Table 2), the approach involves performing a lifecycle cost assessment (LCCA) regarding each household appliance in order to calculate the respective savings as regarding energy consumption $\left(S_{E . \text { Cons }_{i, j}}\left(x_{i j}\right)\right)$, water consumption $\left(S_{H 2 O . C^{2} n s_{i, j}}\left(x_{i j}\right)\right)$, and the initial investment $\left(S_{i n v_{i, j}}\left(x_{i j}\right)\right)$. The equivalent $\mathrm{CO}_{2}$ emissions were then calculated according to [26].

All of the parameters mentioned above, are savings, and they result from the comparison of the efficient and the related standard solution (less sustainable one).

Through the diversity of issues related to each energy service and household appliance, together with the consumer's economic, environmental, and social concerns, a set of attributes was defined based on the consumer's preferences and related to each appliance type/energy service for the three problem dimensions considered, i.e., A-Economics, B-Social, and C-Environment. Such attributes are shown in Table 3. 


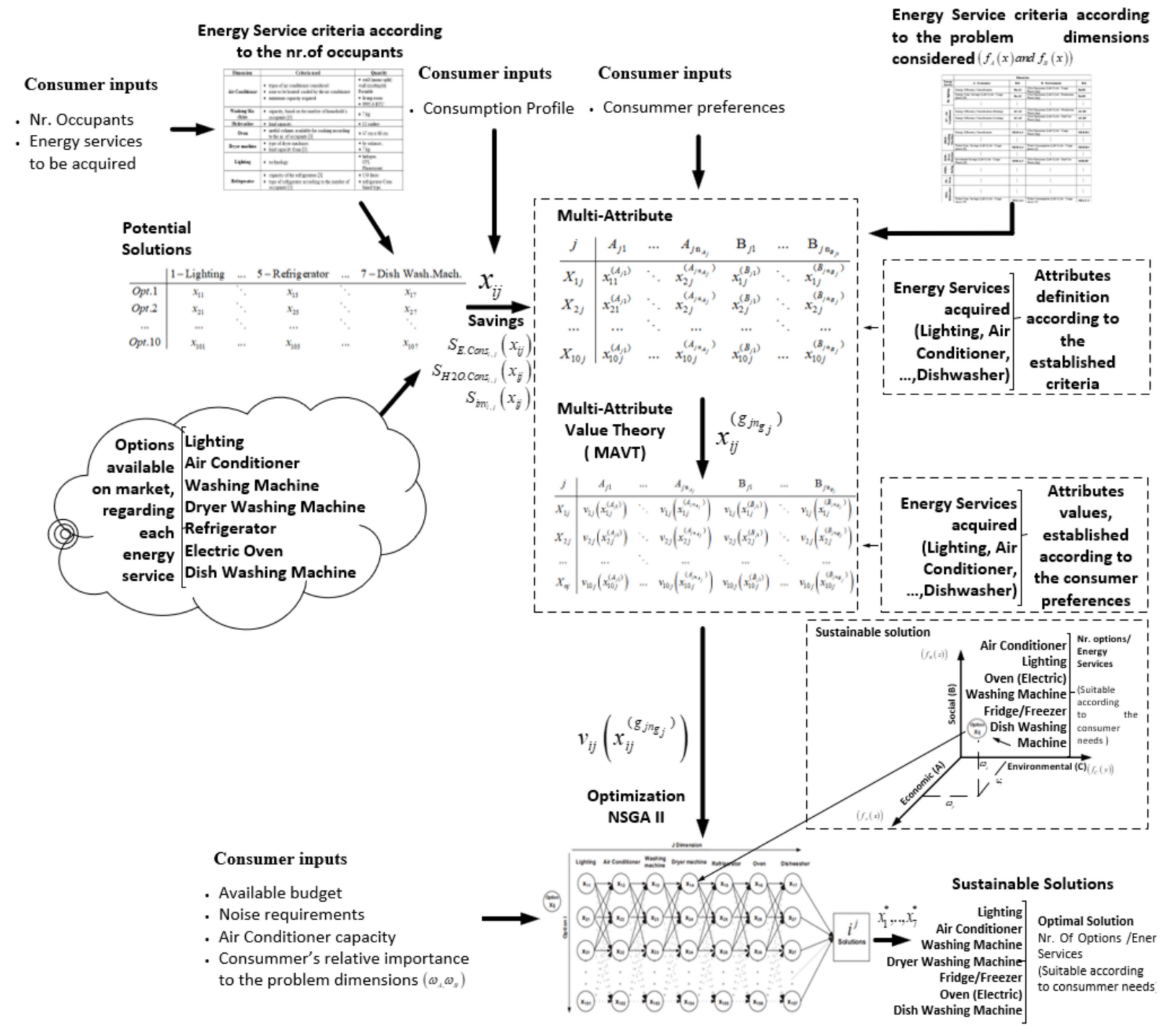

Figure 2. Model proposed (detailed view). 
Table 3. Adopted criteria to define problem dimensions according to the household appliance (energy service) type.

\begin{tabular}{|c|c|c|c|c|c|c|}
\hline \multirow{2}{*}{$\begin{array}{c}\text { Household } \\
\text { Appliance Type }\end{array}$} & Dimension & \multirow{2}{*}{ Ref. } & Dimension & \multirow{2}{*}{ Ref. } & Dimension & \multirow{2}{*}{ Ref. } \\
\hline & A-Economics & & B-Social & & C-Environment & \\
\hline \multirow{3}{*}{ Ilu-light } & Energy Efficiency Labeling & Ilu.A1 & Durability [h) & Ilu.B1 & $\mathrm{CO}_{2} \mathrm{e}$ (Avoided) emissions during the usage phase & Ilu.C1 \\
\hline & & & & & Percentage of recycling material [\%) & Ilu.C2 \\
\hline & $\begin{array}{c}\text { Energy Cons. Savings } \\
\text { (Lifecycle-Usage Phase) [€] }\end{array}$ & Ilu.A5 & $\begin{array}{l}\text { Color Rendering } \\
\text { Index (CRI) [\%) }\end{array}$ & Ilu.B5 & $\mathrm{CO}_{2} \mathrm{e}$ (Avoided) emissions during the production phase & Ilu.C3 \\
\hline \multirow{3}{*}{$\begin{array}{l}\text { AC-Air } \\
\text { Conditioning }\end{array}$} & $\begin{array}{c}\text { Energy Efficiency Labeling } \\
\text { (Heating) }\end{array}$ & AC.A1 & Noise (Indoor) $[\mathrm{dB}$ ) & AC.B1 & $\mathrm{CO}_{2} \mathrm{e}$ (Avoided) emissions during the production phase & AC.C1 \\
\hline & & & & & Products can be repaired by other professionals & AC.C2 \\
\hline & $\begin{array}{c}\text { Energy Efficiency Labeling } \\
\text { (Cooling) }\end{array}$ & AC.A6 & $\begin{array}{l}\text { Customer Service } \\
\text { (Warranty) }\end{array}$ & AC.B9 & $\mathrm{CO}_{2} \mathrm{e}$ (Avoided) emissions during the usage phase & AC.C3 \\
\hline \multirow{3}{*}{ FE-Oven (Electric) } & Energy Efficiency Labeling & FE.A.1 & Design & FE.B1 & $\mathrm{CO}_{2} \mathrm{e}$ (Avoided) emissions during the usage phase & FE.C.1 \\
\hline & & & & & Accessibility (Product repaired by other people) & FEC2 \\
\hline & Investment $\operatorname{cost}[€)$ & FE.A.5 & $\begin{array}{l}\text { Perceived Satisfaction } \\
\text { (by other clients) }\end{array}$ & FE.B.5 & $\mathrm{CO}_{2} \mathrm{e}$ (Avoided) emissions during the end use phase & FE.C.3 \\
\hline \multirow{4}{*}{ MLL_Dishwasher } & Energy Efficiency Labeling & MLL.A.1 & Design & MLL.B.1 & $\mathrm{CO}_{2} \mathrm{e}$ (Avoided) emissions during the usage phase & MLL.C.1 \\
\hline & & & & & $\mathrm{CO}_{2} \mathrm{e}$ (Avoided) emissions during the end use phase & MLL.C2 \\
\hline & & & & & Durability & MLL.C3 \\
\hline & $\begin{array}{c}\text { Water Cons. Savings } \\
\text { (Lifecycle-Usage phase) [€) }\end{array}$ & MLL.A.6 & $\begin{array}{l}\text { Perceived Satisfaction } \\
\text { (by other clients) }\end{array}$ & MLL.B.6 & Water Consumption (Lifecycle-Usage phase) & MLL.C.4 \\
\hline
\end{tabular}


The preferences regarding the social dimension were based on previous works from [20,28], as well as the ones from the economics dimension. The ones from the environmental dimension were chosen based on the works of [29].

Besides the energy efficiency classification label implicit in the attributes presented on Table 3 and referring to each energy service/appliance type considered, all the adopted attributes can be applied into other regions. In this case, the European Union's Energy Labelling Framework regulation (2017/1369) was adopted, considering previous research from $[20,28,29]$. However, with the corresponding adjustments mentioned before, it can be applied into other regions around the world.

The consumption profile was derived by making a set of assumptions based on the hours, which was then extrapolated to a weekly and year base. However, the consumer can also establish their own usage profile based on their needs, or even by using the profile considered in this case study as default values.

As mentioned before, MAVT is employed to support the consumer by assessing a set of alternative solutions based on a set of attributes. These attributes were established on behalf of the three considered dimensions of sustainability (Table 3). Based on Figures 1 and 2, a mathematical model was then defined to obtain the objective functions to be further optimized using NSGAII.

Through these attributes (Table 3$)$, it a decision variable $x_{i j}^{\left(g_{j t}\right)}$ was established that is related to each alternative solution/appliance $i$ regarding a certain appliance type/energy service $j$. This variable is defined based on criteria $t$, associated with the energy service/appliance type $j$ and problem dimension $g$ considered (A-Economics, B-Social, and C-Environmental), i.e.,

$$
g_{j t} \in\left\{\left\{A_{j 1}, A_{j 2}, . . A_{j n_{A_{j}}}\right\} \cup\left\{B_{j 1}, B_{j 2}, . . B_{j n_{B_{j}}}\right\} \cup\left\{C_{j 1}, C_{j 2}, . . C_{j n_{C_{j}}}\right\}\right\}
$$

with

$$
g=\{A, B, C\} \wedge j=\{1,2, . ., 7\} \wedge t=\left\{\left\{1,2, . . n_{A_{j}}\right\} \cup\left\{1,2, . . n_{B_{j}}\right\} \cup\left\{1,2, . . n_{C_{j}}\right\}\right\} \wedge n_{g_{j}}, t, j \in \mathbb{N} .
$$

The numbers $n_{A_{j}}, n_{B_{j}}$, and $n_{C_{j}}$ are regarded with respect to index $t$ as the number of the last criteria $t$ associated to energy service/appliance type $j$ and problem dimension $g$.

Following the notation presented above and according to the criteria established before (Table 3) as well as the assumptions shown in Tables 1 and 2, regarding the case study considered here, the corresponding decision variable regarding each considered attribute $\left(x_{i j}^{\left(g_{j t}\right)}\right)$ can be aggregated and framed into a set of pay-off/behavior tables regarding each energy service $j$. An example of this table is shown in Figure 3a regarding the energy service/appliance type "Air Conditioning". The corresponding table, regarding the corresponding decision values $\left(v_{i j}\left(x_{i j}^{\left(g_{j t}\right)}\right)\right)$, can be achieved using MAVT, and the following relation:

$$
x_{i j}^{\left(g_{j t}\right)} \rightarrow v_{i j}\left(x_{i j}^{\left(g_{j t}\right)}\right) \quad w / x_{i j}^{\left(g_{j t}\right)}, v_{i j}\left(x_{i j}^{\left(g_{j t}\right)}\right) \in \mathbb{R} \wedge i, j \in \mathbb{N} \backslash\{0\}
$$

where

$$
v_{i j}\left(x_{i j}^{\left(g_{j t}\right)}\right)=\left(\frac{\left|x_{i j}^{\left(g_{j t}\right)}-x_{i j(\text { worst })}^{\left(g_{j t}\right)}\right|}{\left|x_{i j(\text { best })}^{\left(g_{j t}\right)}-x_{i j(\text { worst })}^{\left(g_{j t}\right)}\right|}\right) .
$$

Since each decision value $\left(v_{i j}\left(x_{i j}^{\left(g_{j t}\right)}\right)\right)$ works with different scales and units, an expression was used to define the relation between the new and the previous value of $x_{i j}^{\left(g_{j t}\right)}$, respectively $v_{i j}^{(2)}\left(x_{i j}^{\left(g_{j t}\right)}\right)$ and $v_{i j}^{(1)}\left(x_{i j}^{\left(g_{j t}\right)}\right)\left(i . e ., v_{i j}\left(x_{i j}^{\left(g_{j t}\right)}\right)=v_{i j}^{(1)}\left(x_{i j}^{\left(g_{j t}\right)}\right)\right)$, by also using the corresponding worst and best results for a given criterion $g_{j t}$, i.e., 


$$
v_{i j}^{(1)}\left(x_{i j}^{\left(g_{j t}\right)}\right) \rightarrow v_{i j}^{(2)}\left(x_{i j}^{\left(g_{j t}\right)}\right) \quad w / v_{i j}^{(1)}\left(x_{i j}^{\left(g_{j t}\right)}\right), v_{i j}^{(2)}\left(x_{i j}^{\left(g_{j t}\right)}\right) \in \mathbb{R} \wedge i, j \in \mathbb{N} \backslash\{0\}
$$

where

$$
v_{i j}^{(2)}\left(x_{i j}^{\left(g_{j t}\right)}\right)=\left(\frac{\left|v_{i j}^{(1)}\left(x_{i j}^{\left(g_{j t}\right)}\right)-v_{\text {worst }_{i j}}\left(x_{i j}^{\left(g_{j t}\right)}\right)\right|}{\left|v_{\text {better }_{i j}}\left(x_{i j}^{\left(g_{j t}\right)}\right)-v_{\text {worst }_{i j}}\left(x_{i j}^{\left(g_{j t}\right)}\right)\right|}\right) .
$$

The new values of $v_{i j}\left(x_{i j}^{\left(g_{j t}\right)}\right)\left(i . e . v_{i j}\left(x_{i j}^{\left(g_{j t}\right)}\right)=v_{i j}^{(2)}\left(x_{i j}^{\left(g_{j t}\right)}\right)\right)$ fill a new evaluation table belonging to each energy service $j$. On Figure $3 b$, an example is shown of a table regarding the energy service "Lighting".

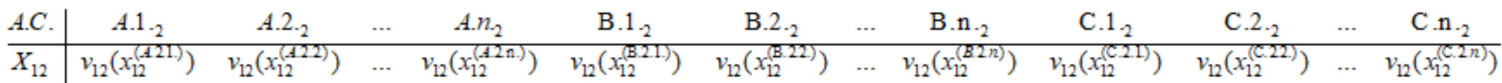

$$
\begin{aligned}
& \begin{array}{lllllllllllll}
X_{22} & v_{22}\left(x_{22}^{(A 21)}\right) & v_{22}\left(x_{22}^{(A 22)}\right) & \ldots & v_{22}\left(x_{22}^{(A 2 n)}\right) & v_{22}\left(x_{22}^{(B 21)}\right) & v_{22}\left(x_{22}^{(B 22)}\right) & \ldots & v_{22}\left(x_{22}^{(B 22 n)}\right) & v_{22}\left(x_{22}^{(C 21)}\right) & v_{22}\left(x_{22}^{(C 22)}\right) & \ldots & v_{22}\left(x_{22}^{(C 2.2)}\right)
\end{array}
\end{aligned}
$$

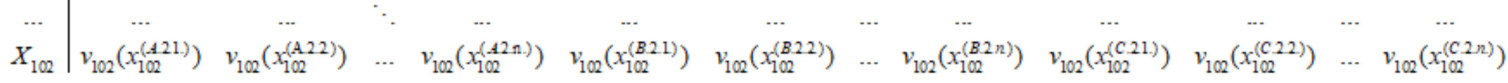

a)

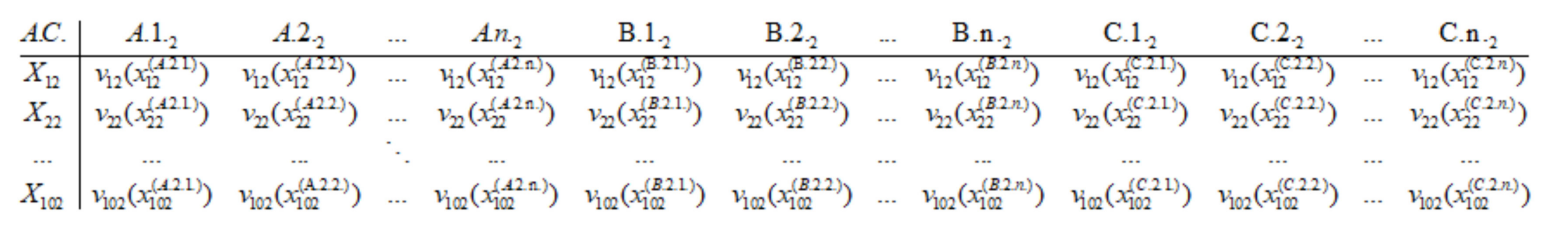

b)

Figure 3. Example of evaluation table (Air Conditioner energy service)): (a) $x_{j}^{\left(g_{j t}\right)} ;(\mathbf{b}) v_{i j}\left(x_{j}^{\left(g_{j t}\right)}\right)$.

Through the value attributes mentioned before, and by using an additive model to aggregate them, a unique model was obtained, represented by an aggregated objective function which was further optimized using the NSGAII algorithm.

As it referred to earlier, the nature of this problem is combinatorial, with the number of combinations being dependent on the size of the sample (22 million combinations considered in this case study).

Additionally, there is a set of constraints that will be considered here to adjust the consumer needs and obtain feasible solutions. These constraints are presented below.

Thus, the problem $\mathrm{p}$ here can be presented as follows:

$$
\begin{array}{ll}
\max \quad V_{m}(x), & c / m=A, B, C \\
\text { subject to } x \in X & c / V_{m}(x)=\left[V_{A}(x), V_{B}(x), V_{C}(x)\right]^{T}
\end{array}
$$

with $\mathrm{x}$ being the decision variable vector, which is defined as

$$
x \in X: x \in\left\{x_{i j}^{\left(A_{j t}\right)}, x_{i j}^{\left(B_{j t}\right)}, x_{i j}^{\left(C_{j t}\right)}\right\} \wedge t, i, j \in \mathbb{N}
$$

where

$$
j=\{1, . ., 10\} \wedge j=\{1,2, . ., 7\} \wedge t=\left\{\left\{1, . ., n_{A_{j}}\right\} \cup\left\{1, . ., n_{B_{j}}\right\} \cup\left\{1, . ., n_{C_{j}}\right\}\right\} \wedge n_{A_{j}}, n_{B_{j}}, n_{C_{j}} \in \mathbb{N}
$$

with $V_{A}(x), V_{B}(x)$, and $V_{C}(x)$ being the objective functions related to each considered sustainability dimension, i.e., A-Economics, B-Social, and C-Environment. 
Each aggregate objective function is given by

$$
V_{g}(x)=\sum_{j=1}^{n_{j}} \sum_{t=1}^{n_{g_{j}}} v_{j}\left(x_{j}^{\left(g_{j t}\right)}\right) w / g=\{A, B, C\} \wedge v_{j}\left(x_{j}^{\left(g_{j t}\right)}\right) \wedge n_{j}, n_{g_{j}}, t, j \in \mathbb{N}
$$

Thus, and through (10), the corresponding objective functions regarding each sustainability dimension can be defined as

$$
\begin{gathered}
\text { Economic Well-being: } \max V_{A}(x)=\sum_{j=1}^{n_{j}} \sum_{t=1}^{n_{A_{j}}} v_{j}\left(x_{j}^{\left(A_{j t}\right)}\right) \\
\text { Social Well - being: } \max V_{B}(x)=\sum_{j=1}^{n_{j}} \sum_{t=1}^{n_{B_{j}}} v_{j}\left(x_{j}^{\left(B_{j t}\right)}\right) \\
\text { Environment Well - being: } \max V_{B}(x)=\sum_{j=1}^{n_{j}} \sum_{t=1}^{n_{B_{j}}}\left(1-v_{j}\left(x_{j}^{\left(C_{j t}\right)}\right)\right)
\end{gathered}
$$

The first and third objective functions are based on the works from [21,29] respectively. The second objective function (Social Wellbeing), is defined based on the attributes established in this work.

Through the use of an additive model developed using MAVT, we have combined the value functions $V_{A}(x), V_{B}(x)$, and $V_{C}(x)$ into a unique aggregated expression which will be the model's objective function. This objective function will be pondered by a weigh factor $\left(\omega_{g}\right)$, expressing, therefore, the relative importance given by the consumer to each sustainability dimension, thus resulting in

$$
V_{\text {Total }}(x)=V\left(V_{A}(x), V_{B}(x), V_{C}(x)\right)=\omega_{A} \cdot V_{A}(x)+\omega_{B} \cdot V_{B}(x)+\omega_{C} \cdot V_{C}(x) .
$$

Therefore, and based on Expression (3), Expression (13) can be described as

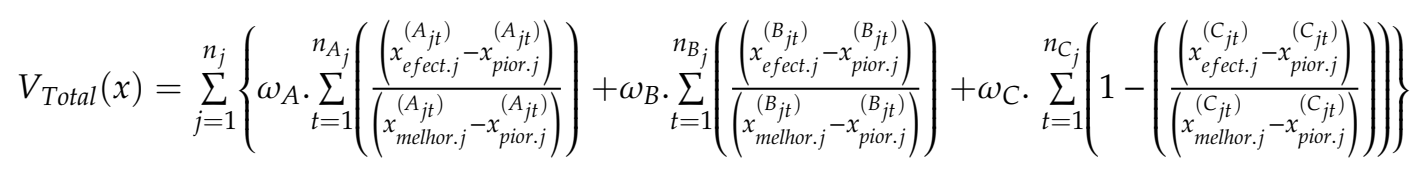

which is subject to a set of constraints regarding economic, social, and environment wellbeing dimensions, namely

Economic-Budget

$$
r_{1}: \sum_{j=1}^{n_{\text {dim }}} I_{j}\left(x_{j}\right) \leq \text { available budget }\left(\eta_{\text {disp. }}\right) \Leftrightarrow \sum_{\substack{j=1 \\ j \neq 2}}^{n_{j}} x_{i j}^{\left(A_{j 4}\right)}+x_{i 2}^{\left(A_{25}\right)} \leq \eta_{\text {disp. }}
$$

Lighting Comfort (minimum illuminance)

$$
r_{2}: \frac{x_{1}^{\left(B_{15}\right)}}{A} K_{1} \geq E_{\min }
$$

Heating/Cooling Requirements

$$
r_{3}: x_{2}^{\left(B_{23}\right)} \geq Q_{\text {th. Aquec. (proj.) }}
$$




$$
r_{4}: x_{2}^{\left(B_{24}\right)} \geq Q_{\text {th. Arref.(proj.) }}
$$

Environment-Noise

$$
\left\{\begin{array}{rl}
r_{51}: x_{i 1}^{\left(B_{11}\right)} & \leq \text { Noise }_{\text {def. } 1} \\
r_{52}: x_{i 2}^{\left(B_{21}\right)} & \leq \text { Noise def. } 2 \\
& \vdots \\
r_{56}: x_{i 6}^{\left(B_{61}\right)} & \leq \text { Noise }_{\text {def. } 6} \\
r_{57}: x_{i 7}^{\left(B_{71}\right)} & \leq \text { Noise }_{\text {def. } .7}
\end{array} \quad c / i=5 \text { e } j=\{2,3,4,5,7\}\right.
$$

Water Consumption

$$
\left\{\begin{array}{l}
r_{61}: x_{i 3}^{(A .3 .6 .)} \times 1 / \tau_{H_{2} O} \leq C_{M L R} \\
r_{62}: x_{i 7}^{(A .7 .5 .)} \times 1 / \tau_{H_{2} O} \leq C_{M L L}
\end{array}\right.
$$

\subsection{Strengths, Weakness, and Limitations of the Work}

The approach presented here uses a lifecycle cost assessment (LCCA) method to predict the cost regarding each solution during its usage phase and according to the consumer's profile.

However, the LCCA calculations only accounts for the cost in terms of water and $\mathrm{CO}_{2}$ emissions involved, and do not consider the materials involved in the production and final phase of the product itself. Further developments regarding this issue should be accounted for in future.

Issues such as the minimal lighting illuminance requirements, the dishwasher capacity, and the air conditioner thermal power (among others) are also accounted for in order to support the consumer with suitable appliances from the market and according to their needs.

Besides the economic and environmental concerns, the consumer's social preferences, such as comfort requirements related to different dimensions (thermal, acoustic, and visual) are also considered here together with different preferences regarding such issues as the (perceived) quality of the product and reliability, among others. The consumer's relative importance, regarding each dimension (economics, social, and environment) are also accounted for here.

Another advantage from the use of this approach is the diversity (although still optimal) of solutions from the market, which allows facing a contingency problem with the availability regarding a specific appliance (e.g., when it is out of stock).

However, the model to calculate the consumer's needs in terms of the air conditioner capacity needs to account not only for the dimensions of the divisions to be climatized but also other issues (e.g., wall materials, the windows, the façade orientation) to increase the precision in obtaining the results by using the model.

Still regarding the lack of precision in the estimation of air conditioner capacity, the model should also account for the dynamics in terms of interdependence between air conditioner and the new lighting system, since that a new lighting system could impact the requirements in terms of building's thermal needs.

Regarding the weakness and strengths already discussed here, there were some limitations within this work. One had to do with dimensions of the database (and, therefore, the sample) that was used, and by considering only the Portuguese market, although the main purpose here was (as an initial phase) to validate the proposed model.

Some attributes used here are only adjusted to the European Union context (e.g., the use of European Union's Energy Labelling Framework as an energy label classification framework), which brings about the requirement to make necessary (and future) adjustments of the method to account for other contexts with respect to the countries or regions involved.

The lack of previous research studies on this topic, given the issues referred to before, also represents a limitation, due to the lack of other approaches to be used as a mean to compare the 
obtained results for example. Therefore, such limitations have allowed for the identification of new gaps in the literature, which point to the need for further developments.

\subsection{The Optimization Method Non-Dominated Sorting Genetic Algorithm II (NSGAII)}

As it mentioned before, NSGAII was used in this work as a multiobjective optimization method based on evolutionary algorithms. The motivation for its use is based on its success in other approaches, which are related to problems of the same nature, in addition with its perceived advantages [19,29].

Thus, the method presented in this work uses NSGAII to deal with a set of candidate solutions, which are assessed by using an approach of multicriteria analysis integrated with MAVT.

Regarding NSGAII and the individual's codification, the adopted was realistic given the nature of the decision variables used in this work.

The corresponding individual's framework is presented as follows in Figure 4.

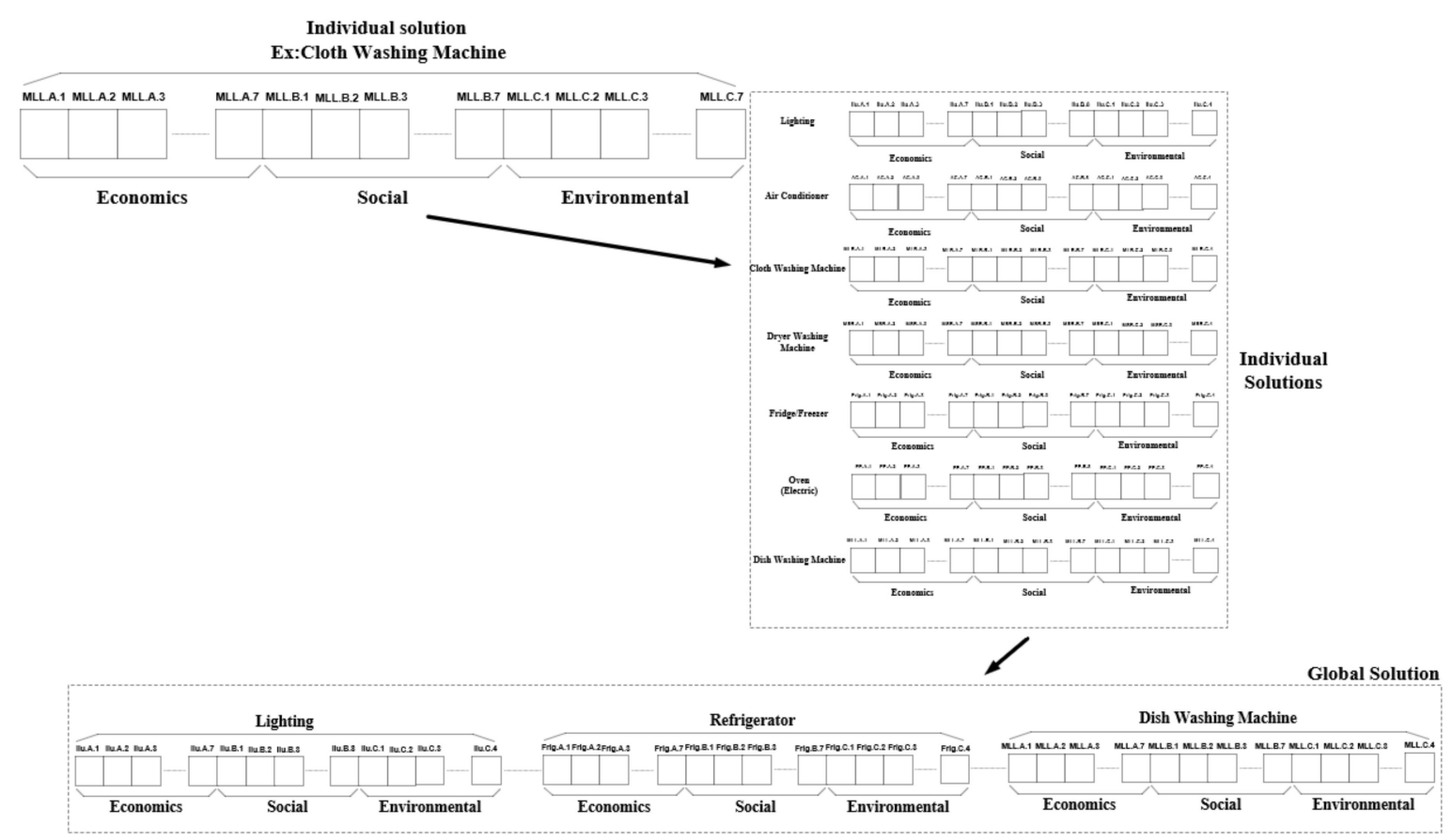

Figure 4. Individual framework.

According to [21,29], the NSGA's iteration process, applied here, uses several steps (Figure 5) consisting of initialization, crossover, and selection. Parameters such as the size of population, the iteration size, and crossover rate were determined empirically through a robustness analysis together with statistical analysis.

Based on Figure 5, the stopping criterion is defined by the variable "gen" regarding the maximum number of generations of NSGAII.

After the achievement of the feasible solutions/individuals, regarding each generation, they are selected from the parents and offspring. The last solution, results from the application of crossover and mutation. The process is finished, whenever the maximum number of iterations (defined by the user as a stop criteria) is surpassed.

The corresponding Pareto frontier is then obtained when we are dealing with a NSGAII with two objective functions, while a Pareto surface is found when we are dealing with a NSGAII with three objective functions. 


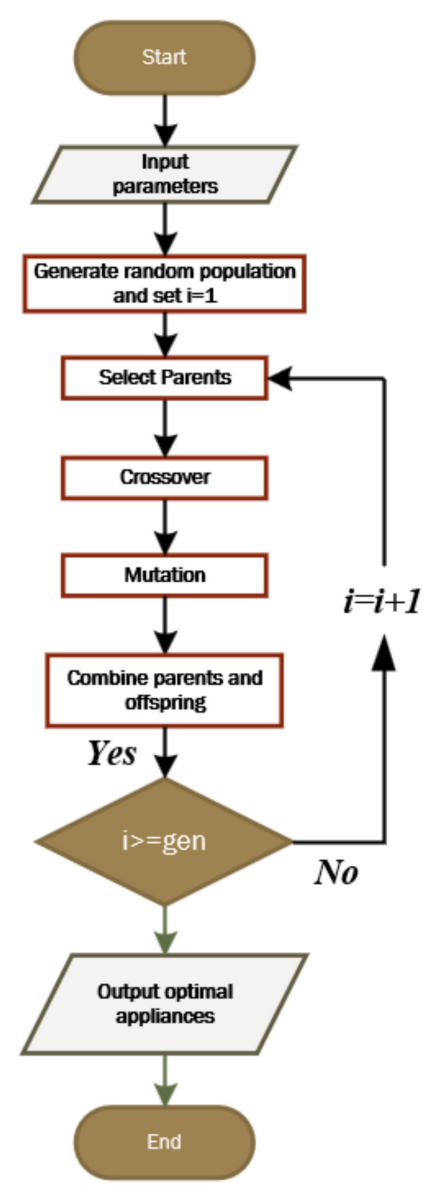

Figure 5. Non-dominated sorting genetic algorithm II (NSGAII) flowchart.

\section{Results and Discussion}

The proposed model was then applied to the case study considered here. After defining the calculations according to LCCA, and regarding each individual solution as well as the corresponding attributes according to MAVT (Appendices A and B), the optimization process took place using the NSGAII algorithm. The corresponding algorithm was then coded on MATLAB software, by accounting for the following parameters:

- Selection method: tournament

- Crossover method: double point

- Mutation method: random mutation (one point)

The remaining parameters, namely the initial population, crossover, and mutation rate, were established after several trials.

The first parameter to be tested was the stopping criterion "max number of generations", where several runs were performed considering the corresponding values of 80 and 90 (Figure 6a,b respectively).

A maximum number of iterations (generations) of 80 was also defined, which was achieved given the neglectable difference obtained between the corresponding Pareto fronts (Figure $6 a, b$ ) regarding both scenarios, i.e., Economics \& Environment $\left(\omega_{\mathrm{A}}=0.65, \omega_{\mathrm{B}}=0.00\right.$, and $\left.\omega_{\mathrm{C}}=0.35\right)$ and Economics \& Social $\left(\omega_{\mathrm{A}}=0.65, \omega_{\mathrm{B}}=0.35\right.$, and $\left.\omega_{\mathrm{C}}=0.00\right)$.

Other parameters were also determined, such as the size of population (150 individuals), the size of tournament (10), the rate of crossover (0.75), and the rate of mutation (0.25).

In order to better analyze the fitness behavior considering different values of mutation and the crossover rate, a robustness test was performed considering two scenarios and regarding the considered 
case study, i.e., Economics \& Environment $\left(\omega_{\mathrm{A}}=0.65, \omega_{\mathrm{B}}=0.00\right.$, and $\left.\omega_{\mathrm{C}}=0.35\right)$ and Economics \& Social $\left(\omega_{\mathrm{A}}=0.65, \omega_{\mathrm{B}}=0.35\right.$, and $\left.\left.\omega_{\mathrm{C}}=0.00\right)\right)$. The fixed parameters were the size of population (100 individuals) and the size of the tournament (12 individuals).

The rates regarding the mutation and crossover operators were then changed by performing several trials of crossover and mutation values (Table 4).

All the trials shown in Table 4, were executed by setting a maximum number of iterations (90).

The respective results are shown on Figure $7 \mathrm{a}, \mathrm{b}$, for each considered scenario. It is noted that a small change in the value of each parameter, has a negligible effect in the obtained results, considering both scenarios.

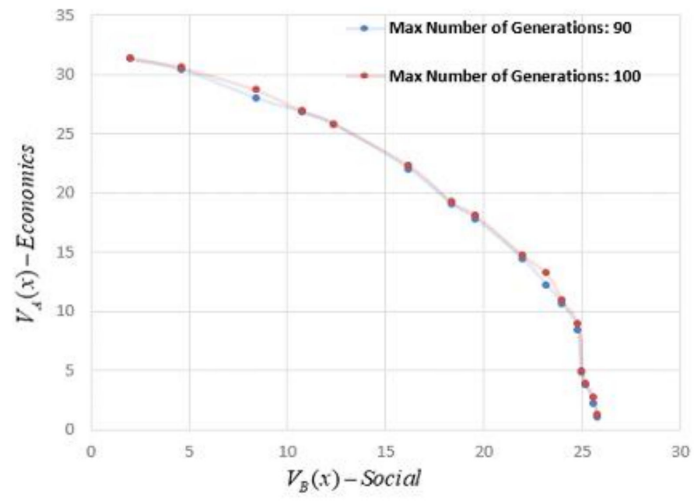

(a)

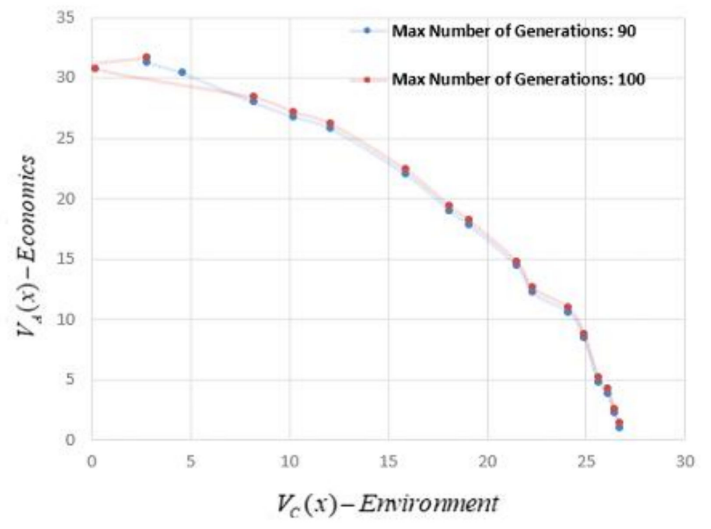

(b)

Figure 6. Pareto frontier regarding the 80th and 90th generations. $(a)\left(\omega_{A}=0.65 ; \omega_{B}=0.35 ; \omega_{C}=0.00\right)$; (b) $\left(\omega_{\mathrm{A}}=0.65 ; \omega_{\mathrm{B}}=0.00 ; \omega_{\mathrm{C}}=0.35\right)$.

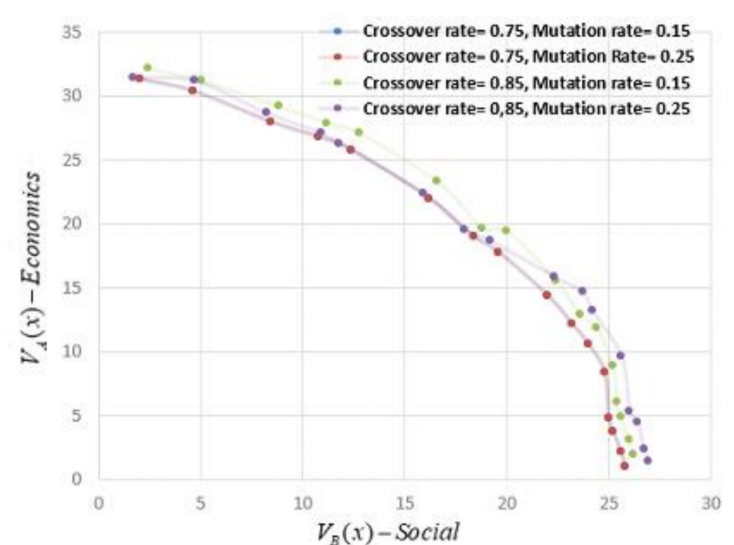

(a)

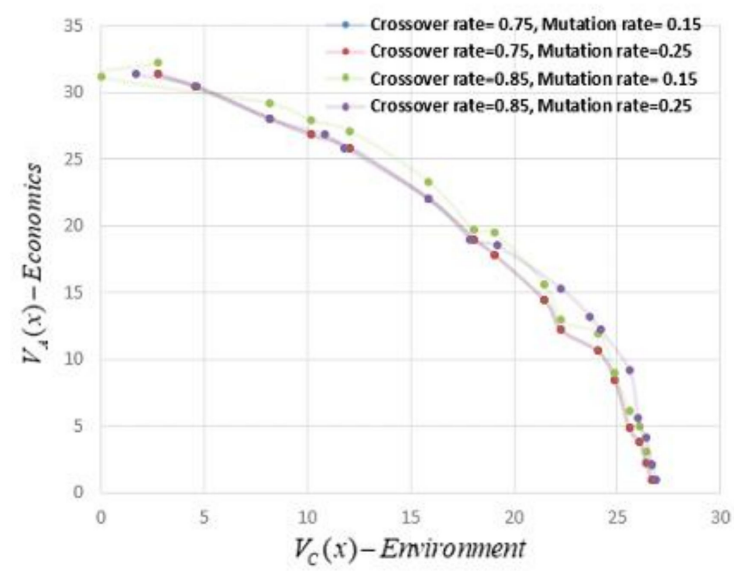

(b)

Figure 7. Pareto frontier considering different values of crossover and mutation rate. $(\mathbf{a})\left(\omega_{\mathrm{A}}=0.65\right.$; $\left.\omega_{\mathrm{B}}=0.35 ; \omega_{\mathrm{C}}=0.00\right) ;(\mathbf{b})\left(\omega_{\mathrm{A}}=0.65 ; \omega_{\mathrm{B}}=0.00 ; \omega_{\mathrm{C}}=0.35\right)$.

Therefore, the parameters NSGAII that were used to show the sustainable results obtained in this case study, were tournament size (10), max iteration (90), population size (100), mutation rate (0.1) and crossover rate (0.9).

After performing NSGAII calculations, a Pareto frontier is obtained by accounting for the scenarios described above for Economics vs. Social $\left(\omega_{\mathrm{A}}=0.65, \omega_{\mathrm{B}}=0.35\right.$, and $\left.\omega_{\mathrm{C}}=0.00\right)$ and Economics vs. Environment $\left(\omega_{\mathrm{A}}=0.65, \omega_{\mathrm{B}}=0.00\right.$, and $\left.\omega_{\mathrm{C}}=0.35\right)$ (Figure $8 \mathrm{a}, \mathrm{b}$ respectively). 
Table 4. Crossover's and mutation values considered.

\begin{tabular}{ccc}
\hline Trial & Crossover Value & Mutation Value \\
\hline 1 & 0.75 & 0.15 \\
2 & 0.75 & 0.25 \\
3 & 0.85 & 0.15 \\
4 & 0.85 & 0.25 \\
\hline
\end{tabular}

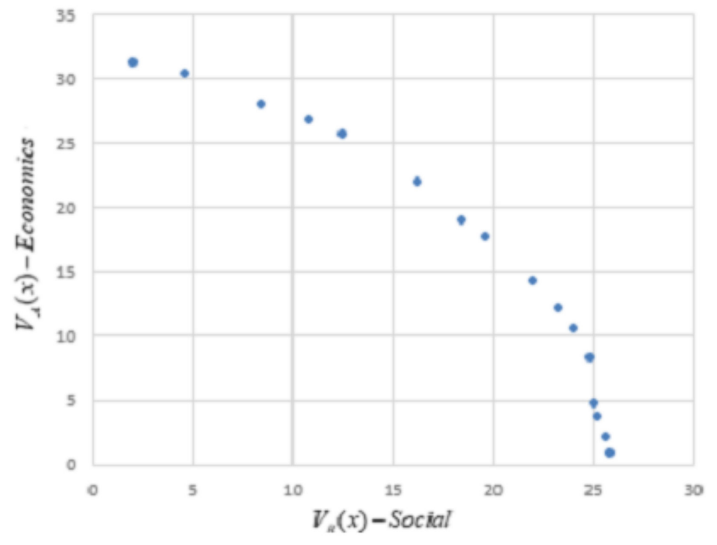

(a)

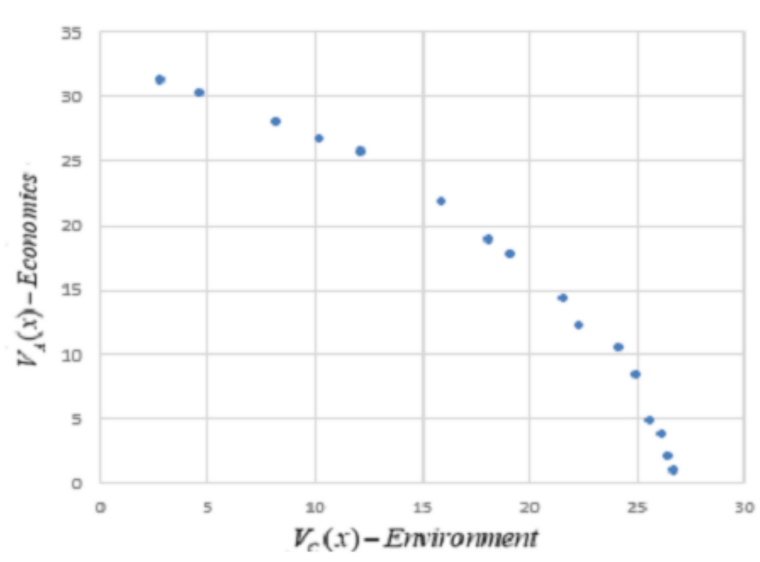

(b)

Figure 8. Pareto frontier: $(\mathbf{a})\left(\omega_{\mathrm{A}}=0.65 ; \omega_{\mathrm{B}}=0.35 ; \omega_{\mathrm{C}}=0.00\right) ;(\mathbf{b})\left(\omega_{\mathrm{A}}=0.65 ; \omega_{\mathrm{B}}=0.00 ; \omega_{\mathrm{C}}=0.35\right)$.

Each point (or node) represents a global sustainable solution of the problem formed by a set of sustainable (and individual) solutions (household appliances) regarding each appliance type to be acquired by the consumer.

Although the Economic wellbeing decreases, the Social one increases (Figure 8a), with the same trade-off, being observed in Figure 8b, by considering only Economic and Environmental wellbeing dimensions.

Regarding the case study considered here and based on both trade-offs presented above, a scenario was considered with three dimensions and their corresponding consumer's relative importance, represented by the corresponding weights, i.e., $\omega_{\mathrm{A}}=0.65, \omega_{\mathrm{B}}=0.25$, and $\omega_{\mathrm{C}}=0.10$.

The corresponding Pareto surface is obtained in Figure 9.

Based on the obtained Pareto surface (Figure 9), the crowding distance that resulted from each individual solution is higher in the region where the Economic dimension has more dominance, followed by the Social and, at last, the Environmental one. Such an order of dominance between each dimension of sustainability is somehow expected, given the relative importance values (weight) considered in this case for each dimension $\left(\omega_{\mathrm{A}}=0.65, \omega_{\mathrm{B}}=0.25\right.$, and $\left.\omega_{\mathrm{C}}=0.10\right)$.

One of the nodes from that region is shown on Table 5 , regarding a sustainable solution obtained by considering a budget constraint of $€ 2500$ and a consumer lifecycle of 10 years.

The avoided $\mathrm{CO}_{2}$ emissions for each appliance are also shown, and they result from the comparison between the "sustainable" solution achieved and the "less sustainable" one, i.e., the standard solution.

The investment as well as the consumption savings were also obtained based on the difference between the "sustainable" solution achieved and the "less sustainable" one, and by also considering the lifecycle period regarding each energy service. Therefore, the corresponding monetary flows were then discounted to the present period in order to calculate the present value of each investment as well as each consumption value regarding the sustainable and less sustainable solutions.

Considering the results presented on Table 5, the consumer can achieve energy savings of around $€ 2112.30$ regarding the considered lifecycle. 
Table 5. One of sustainable solutions achieved from the Pareto surface $\left(\omega_{\mathrm{A}}=0.65, \omega_{\mathrm{B}}=0.25\right.$, and $\left.\omega_{\mathrm{C}}=0.10\right)$.

\begin{tabular}{|c|c|c|c|c|c|c|c|c|}
\hline $\begin{array}{l}\text { Electrical Household } \\
\text { Appliance }\end{array}$ & $\begin{array}{l}\text { Standard Solution } \\
\text { Total Invest, }(\boldsymbol{\epsilon})\end{array}$ & $\begin{array}{l}\text { Sust. sol. Total } \\
\text { Invest (€) }\end{array}$ & $\begin{array}{l}\text { Inv. Saving } \\
(\boldsymbol{(})\end{array}$ & $\begin{array}{l}\text { Energy Consump. } \\
\text { Savings }(€)\end{array}$ & $\begin{array}{l}\text { Water Consump. } \\
\text { (avoided) (l) }\end{array}$ & $\begin{array}{l}\mathrm{CO}_{2} \text { Emissions } \\
\text { (avoided) (kg) }\end{array}$ & Manuf. & Model Type \\
\hline Light & 16.88 & 49.04 & 5.35 & 62.20 & - & 27.60 & Phillips & LEDspo \\
\hline Air conditioning & 352.00 & 279.00 & 69.00 & 1319.50 & - & 1322.60 & Samsung & AQV09 \\
\hline Refrigerator & 234.00 & 399.00 & -265.00 & 709.30 & - & 9.72 & Becken & Bc2016 I \\
\hline Washing machine & 272.20 & 249,90 & $-33,00$ & 5.60 & 322.10 & 95.10 & INDESIT & EWE71 \\
\hline Dishwasher machine & 310.00 & 349.00 & -39.00 & 3.20 & 423.00 & 6.90 & LG & DF212F \\
\hline Oven & 171.00 & 701.00 & -28.30 & 2.82 & - & 2.33 & Electrolux & $\mathrm{EZC} 243$ \\
\hline Clothes dryer & 368.00 & 449.00 & -68.00 & 10.20 & - & 1.82 & Bosch & WTE841 \\
\hline Total & 1724.80 & 2475.94 & -262.65 & 2112.30 & 745.10 & 1458.90 & - & - \\
\hline
\end{tabular}

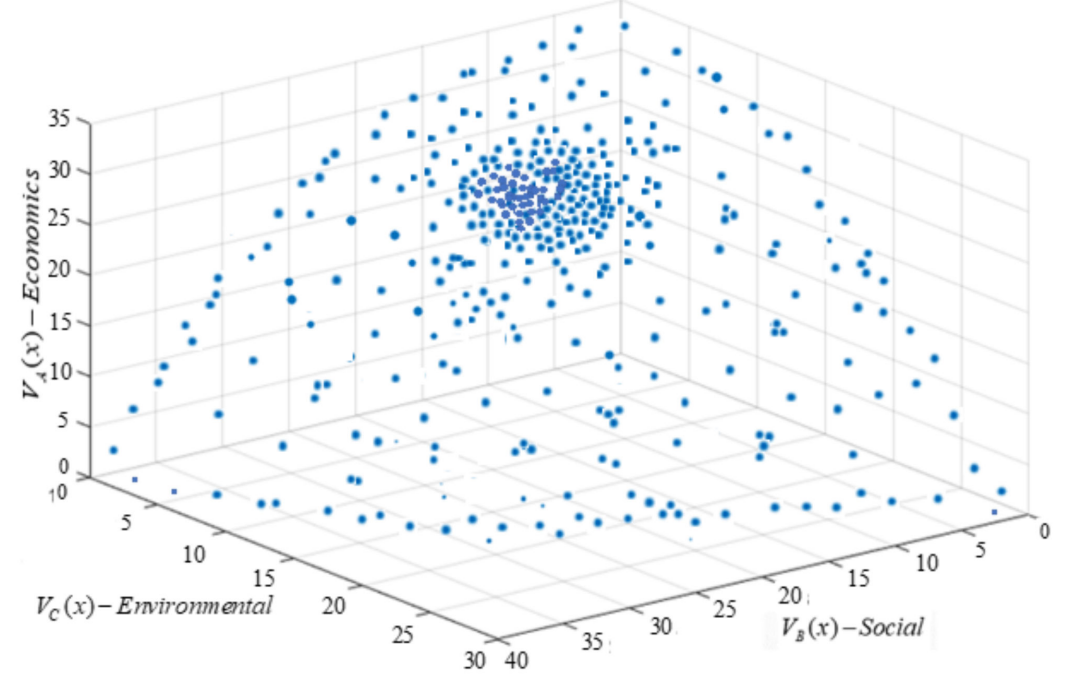

Figure 9. Pareto surface $\left(\omega_{\mathrm{A}}=0.65 ; \omega_{\mathrm{B}}=0.25 ; \omega_{\mathrm{C}}=0.10\right)$. 
Based on this value, we can estimate a consumption average value of $211.23 € /$ year (previous result divided by the considered lifecycle), which is lower than the average value of 300 in [9], although still significant, thus highlighting the importance of achieving energy savings during the lifecycle of each equipment.

During the considered lifecycle, the consumer can also avoid $1458.90 \mathrm{~kg}$ of $\mathrm{CO}_{2}$ emissions and avoid consumption of approximately 745.10 liters of water, with both resulting in savings.

\section{Conclusions \& Future Work}

In this paper, a decision support method was presented to provide sustainable household appliances from the market to a consumer by considering three dimensions of sustainability, namely, economics, social, and environmental wellbeing.

The proposed approach has made use of a set of established criteria, in order to pre-select a set of candidate solutions from the market, and by following the consumer requirements. The use of such criteria (adjustable to each consumer's requirements), allows for definition of the decision space, composed by a set of candidate solutions according to each type of appliance to be considered by the consumer.

Additional criteria were used and integrated with MAVT in order to model the consumer preferences according to the three problem dimensions presented here. The main purpose of these procedures was to maximize consumer wellbeing by acting on the three problem dimensions referred to above, and according to the relative importance given by the consumer.

After modeling the preferences of the consumer, where the ecological impact (e.g., $\mathrm{CO}_{2}$ and water savings) and economic issues (energy consumption and initial investment savings) based on the lifecycle cost assessment (LCCA) of each household appliance were also taken into account, NSGAII was then applied to maximize the three objective functions referred to earlier.

The method presented in this work allows for maximizing all three dimensions of sustainability by acquiring a set of sustainable (and alternative) appliances from the market suitable for each consumer's preferences and concerns. This also allows the consumer to achieve a set of savings regarding energy consumption, $\mathrm{CO}_{2}$ emissions, and water consumption.

There are some limitations, as pointed out earlier, as well as weaknesses that could be improved in the model in future, in order to make it more precise and suitable for the consumer.

Thus, and based on the limitations mentioned before, all of the adopted attributes can be used in other regions, although with necessary adjustments, given the existence of some differences regarding the region or country involved (e.g., energy labeling classification frameworks).

Besides the limitations identified earlier, which can be used as a basis to develop future work, the approach developed here can also be extended into other energy services with a relevant impact in terms of sustainable development, such as regarding information technology equipment (e.g., computers, printers, among others).

Furthermore, the use of indicators, such as the European Smart Readiness Indicator (SRI), can also be considered here as a future development by integrating the method developed in this paper into the SRI framework in order to better adjust each building (and it units) to each consumer's needs.

Author Contributions: R.S. and A.A., conceived and designed the experiments; F.M. and A.A., performed the experiments; J.M.C. and J.S., analyzed the data; J.S. and J.M.F.C., contributed analysis tools; R.S., wrote the paper. All authors have read and agreed to the published version of the manuscript.

Funding: This research received no external funding.

Conflicts of Interest: The authors declare no conflict of interest. 


\section{Appendix A}

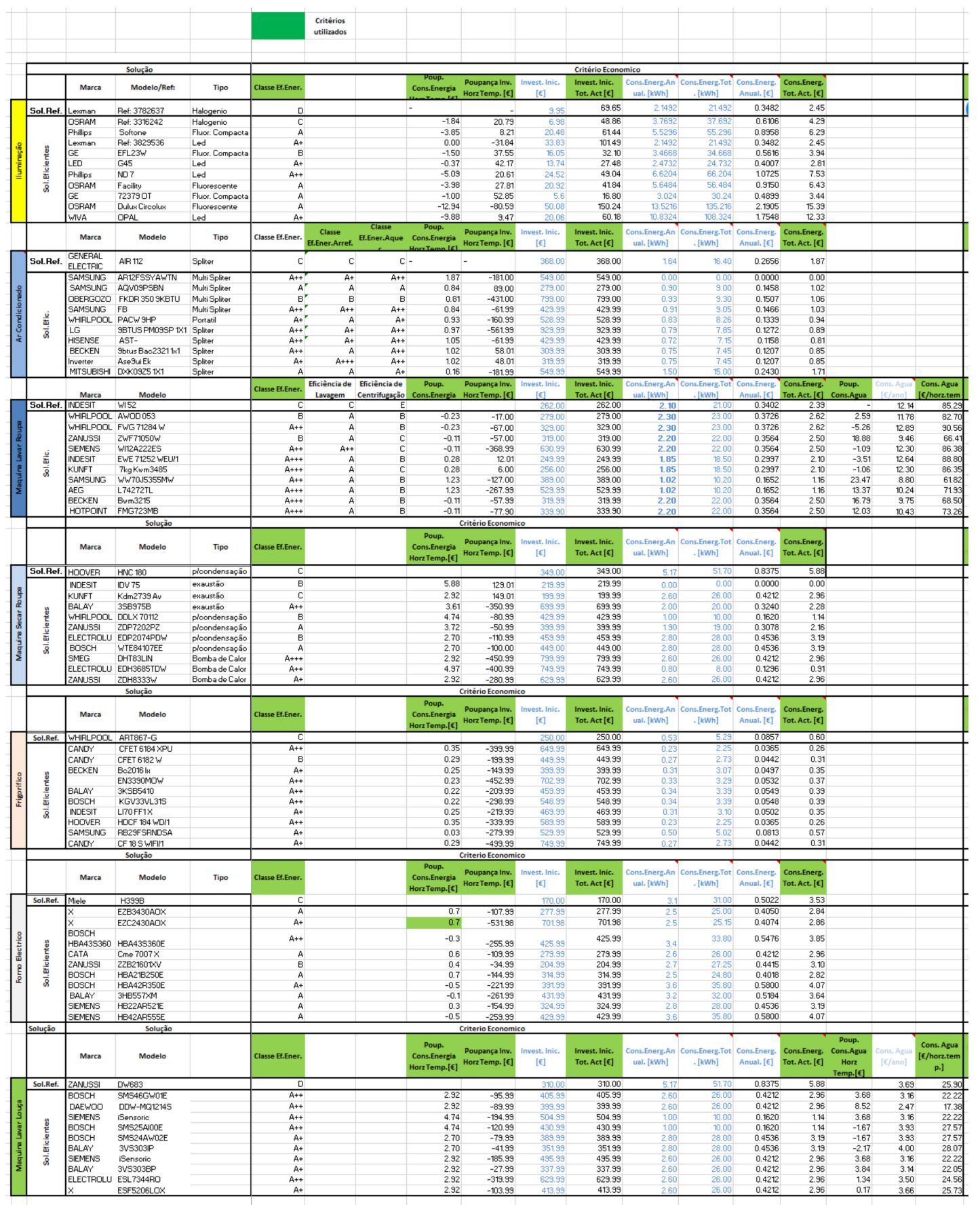

Figure A1. Cont. 


\begin{tabular}{|c|c|c|c|c|c|c|c|c|c|c|c|c|c|c|}
\hline & & & Solução & & & & & Critério Social & ial|Conforto, & Gostos, Percep & pcôes) & & & \\
\hline & & Marca & Modelo/Ret: & Tipo & Durabilidade (hrs) & IRC & $\begin{array}{l}\text { Frequ.Subst. } \\
\text { Lampadas } \\
\end{array}$ & $\begin{array}{c}\text { Qualidade } \\
\text { (Fiabilidade) }\end{array}$ & $\begin{array}{c}\text { Fluxo } \\
\text { Luminoso }\end{array}$ & & & & & \\
\hline & Sol.Ref. & Lesman & Ref: 3782637 & Halogenio & 1900 & 100 & 6 & 7 & 1200 & & & & & \\
\hline & & $\begin{array}{l}\text { OSPAAM } \\
\text { Philios }\end{array}$ & Ref: 3316242 & Halogenio & 2000 & 100 & 6 & 9 & 1230 & & & & & \\
\hline & & $\begin{array}{l}\text { Phillips } \\
\text { Lemanan }\end{array}$ & $\begin{array}{l}\text { Sottone } \\
\text { Ref } 3829536\end{array}$ & Fluor. Compacta & 10000 & 85 & 2 & 10 & 1200 & & & & & \\
\hline . & g & $\begin{array}{l}\text { Lestman } \\
\text { GE }\end{array}$ & $\begin{array}{l}\text { Ree: } 18229536 \\
\text { EFL23W }\end{array}$ & $\begin{array}{l}\text { Led } \\
\text { Fluor. Compacta }\end{array}$ & $\begin{array}{l}10000 \\
15000\end{array}$ & $\begin{array}{l}80 \\
85\end{array}$ & ${ }_{1}^{2}$ & $\begin{array}{l}7 \\
8\end{array}$ & $\begin{array}{l}\begin{array}{l}1400 \\
1258\end{array} \\
\end{array}$ & & & & & \\
\hline & & LED & G45 & & 25000 & 80 & 1 & 4 & 1258 & & & & & \\
\hline$\underline{3}$ & 递 & Phillips & ND7 & Led & 15000 & 80 & 1 & 10 & 1000 & & & & & \\
\hline & $\bar{\Omega}$ & OSRAM & & Fluorescente & 11000 & 75 & 1 & 9 & 1450 & & & & & \\
\hline & & GE & $723790 \mathrm{~T}$ & Fluor. Compacta & 10000 & 85 & 2 & 8 & 1238 & & & & & \\
\hline & & $\begin{array}{l}\text { OSRAM } \\
\text { WIVA }\end{array}$ & $\begin{array}{l}\text { Dulux Ciroolus } \\
\text { OPAL }\end{array}$ & $\begin{array}{l}\text { Fluoressente } \\
\text { Led }\end{array}$ & $\begin{array}{l}10000 \\
10000\end{array}$ & $\begin{array}{l}85 \\
85 \\
85\end{array}$ & 2 & $\frac{10}{4}$ & $\begin{array}{l}1200 \\
1400 \\
-1\end{array}$ & & & & & \\
\hline & & & & & & & & & & & & & & \\
\hline & & Marca & Modelo & Tipo & Pot. Son. (lint)./da] & (Ext)][dB] & (Arref). $[\mathrm{kW}]$ & (Aquec.) [kW] & desum. & Filtro Ar & (Fiablildade) & Funcionalidades & Design & venda (Garantia) \\
\hline & Sol.Ref. & $\begin{array}{l}\text { GEENERAL } \\
\text { ELECTRIC }\end{array}$ & AlR 112 & Spliter & 42.00 & 42.00 & 3.15 & 11.93 & Năo & Sim & 92.12 & 88.923 & 36.00 & 93.00 \\
\hline & & $\begin{array}{l}\text { SAMSUNG } \\
\text { SAMSUNG }\end{array}$ & $\begin{array}{l}\text { AR12FSSYAWTN } \\
\text { AQVOPPSEN }\end{array}$ & $\begin{array}{l}\text { Multi Spliter } \\
\text { Mulis }\end{array}$ & $\begin{array}{l}60.00 \\
36.00\end{array}$ & $\begin{array}{l}59.00 \\
3600\end{array}$ & 3.52 & 0.00 & Sim & Sim & 92.12 & 88.92 & 38.00 & 85.00 \\
\hline ํㅝㄹ & & $\begin{array}{l}\text { SAASUONG } \\
\text { OBERGOZO }\end{array}$ & $\begin{array}{l}\text { ALVDGPSEN } \\
\text { FKD 350 }\end{array}$ & $\begin{array}{l}\text { Multispoliter } \\
\text { Muti Spliter }\end{array}$ & $\begin{array}{l}36.00 \\
56.00\end{array}$ & $\begin{array}{l}36.00 \\
55.00\end{array}$ & $\begin{array}{l}2.24 \\
5.28\end{array}$ & 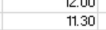 & $\begin{array}{l}\text { Sim } \\
\text { Nằo }\end{array}$ & $\begin{array}{l}\text { Sim } \\
\text { Nằ }\end{array}$ & $\begin{array}{l}92.12 \\
96.26\end{array}$ & 98.92 & 8.00 & $\begin{array}{l}85.00 \\
94.00\end{array}$ \\
\hline & & SAMSUNNG & & Mukti Spliter & 57.00 & 56.00 & 3.30 & 18.00 & Sim & Sim & 97.30 & 93.923 & & 85.00 \\
\hline$\overline{\mathrm{z}}$ & 品 & WHIRLPOOL & PACW $9 H P$ & Portatil & 64.00 & 63.00 & 3.00 & 9.90 & Nằ & Năం & 92.12 & 88.92 & 27.00 & 95.00 \\
\hline & $\overline{\frac{1}{Q}}$ & & 9BTUS PMOSSP 1X1 & Spliter & 57.00 & 56.00 & 2.50 & 9.99 & Sim & Sim & 87.98 & 84.923 & 35.00 & 89.00 \\
\hline 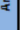 & & $\begin{array}{l}\text { HISENSE } \\
\text { BECKEN }\end{array}$ & $\begin{array}{l}\text { AST- } \\
\text { 9busac23211\%1 }\end{array}$ & $\begin{array}{l}\text { Spliter } \\
\text { Soltiter }\end{array}$ & 62.00 & 60.00 & 2.64 & 9.78 & Sim & Sim & 90.05 & 86.927 & 16.00 & 41.00 \\
\hline & & BECKEN & $\begin{array}{l}\text { Sbtus Bac2321 } 1 \times 1 \\
\text { Asegrivk }\end{array}$ & $\begin{array}{l}\text { Spliter } \\
\text { Soltiter }\end{array}$ & 54.00 & $\begin{array}{l}50.00 \\
5500\end{array}$ & $\begin{array}{l}2.50 \\
270 \\
-30\end{array}$ & 9.10 & $\begin{array}{l}\text { Năo } \\
\text { Sim }\end{array}$ & Năo & $\begin{array}{l}96.26 \\
86.95\end{array}$ & 92.927 & 19.00 & 87.00 \\
\hline & & 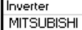 & $\begin{array}{l}\text { Asequide } \\
\text { DXK0925 1X1 }\end{array}$ & $\begin{array}{l}\text { Spliter } \\
\text { Spliter }\end{array}$ & $\begin{array}{l}52.00 \\
27.00\end{array}$ & $\begin{array}{l}\begin{array}{l}52.00 \\
27.00\end{array} \\
\end{array}$ & $\begin{array}{l}2.70 \\
2.64\end{array}$ & $\begin{array}{l}9.12 \\
9.00\end{array}$ & $\begin{array}{l}\text { Sim } \\
\text { Nằo }\end{array}$ & $\begin{array}{l}\text { Sim } \\
\text { Sim }\end{array}$ & $\begin{array}{l}86.95 \\
89.02\end{array}$ & $\begin{array}{l}83.922 \\
85.92\end{array}$ & 20.00 & $\begin{array}{l}85.00 \\
88.00\end{array}$ \\
\hline & & & & & & Capacidade & & & & & Qualidade & & & Assistencia Pos- \\
\hline & & Marca & Modelo & & Ruido(dB) & Nominal [kes] & & & & & (Fiabilidade) & Funcionalidades & Design & venda (Garantia) \\
\hline & $\begin{array}{l}\text { Sol.Ref. } \\
\end{array}$ & $\begin{array}{l}\text { INOESIT } \\
\text { IOTI }\end{array}$ & W52 & & 56.00 & 7.00 & & & & INDESIT & 89.00 & 86.338 & & 98 \\
\hline & & WHIRLPOOL & AW00 053 & & 46.00 & 7.00 & & & & WHIFLPOOL & 89.00 & $86.33 \mathrm{k}$ & & 95 \\
\hline & & WHIRLPOOL & FWG $71284 \mathrm{~W}$ & & 49.00 & 7.00 & & & & WHIRLPOOL & 89.00 & 86.33 & & 87 \\
\hline \& & & ZANusSI & ZWF71050W & & 48.00 & 6.00 & & & & ZANUSSI & 93.00 & 90.21 & & 84 \\
\hline & & SIEMENS & W112A222ES & & 48.00 & 7.00 & & & & SIEMENS & 94.00 & $91.18 \mathrm{~s}$ & & 92 \\
\hline & 递 & INDESIT & EWE 71252 WEU/1 & & 60.00 & 7.00 & & & & INDESIT & 89.00 & 86.33 & & 87 \\
\hline & $\bar{\Omega}$ & KUNFT & $7 \mathrm{~kg}$ Kwm 3485 & & 58.00 & 6.00 & & & & KUNFT & 85.00 & 82.45 & & 94 \\
\hline & & $\begin{array}{l}\text { SAMSUNG } \\
\text { AEG }\end{array}$ & $\begin{array}{l}\text { WW/70.55355MW } \\
\text { t74272TL }\end{array}$ & & $\begin{array}{l}62.00 \\
5700\end{array}$ & 7.00 & & & & $\begin{array}{l}\text { SAMSUNG } \\
\text { AEG }\end{array}$ & $\begin{array}{l}87.00 \\
9300\end{array}$ & 84.39 \& & 87.87 & 95 \\
\hline$\Sigma$ & & $\begin{array}{l}\text { AEG } \\
\text { BECKEN }\end{array}$ & $\begin{array}{l}\mathrm{L} 742722 \mathrm{~L} \\
\mathrm{~B} w \mathrm{~m} 3215\end{array}$ & & $\begin{array}{l}57.00 \\
58.00\end{array}$ & $\begin{array}{l}7.00 \\
700\end{array}$ & & & & $\begin{array}{l}\text { AEG } \\
\text { BECKEN }\end{array}$ & 93.00 & $\begin{aligned} 90.21 \mathrm{~s} \\
8148\end{aligned}$ & $\begin{array}{l}93.93 \\
8.84\end{array}$ & 99 \\
\hline & & $\begin{array}{l}\text { EECKEN } \\
\text { HOTPOINT }\end{array}$ & $\begin{array}{l}\text { BwW32315 } \\
\text { FMG }\end{array}$ & & $\begin{array}{l}58.00 \\
62.00\end{array}$ & $\begin{array}{l}7.00 \\
7.00 \\
\end{array}$ & & & & $\begin{array}{l}\text { BECKEN } \\
\text { HOTPOINT }\end{array}$ & $\begin{array}{l}84.00 \\
86.00\end{array}$ & $\begin{array}{l}81.48 \mathrm{8} \\
83.428\end{array}$ & 86.84 & $\begin{array}{l}97 \\
89\end{array}$ \\
\hline & & & Solução & & & & & Critério Social & ial|Conforto, & Gostos, Percep & pcões) & & & \\
\hline & & Marca & Modelo & Tipo & Pot.Son.Sec, [dB] & $\begin{array}{c}\text { Capacidade } \\
\text { Nominal [kes] }\end{array}$ & & & & & $\begin{array}{c}\text { Qualidade } \\
\text { (Fiabilidade) }\end{array}$ & $\begin{array}{l}\text { Nr. } \\
\text { Funcionalidades }\end{array}$ & Design & $\begin{array}{l}\text { Assistencia Pos- } \\
\text { venda (Garantia) }\end{array}$ \\
\hline & Sol.Ref. & HOOVER & HNC 180 & ploondensação & 60.00 & 6.00 & & & & & 95.00 & 86.45 & & 91.00 \\
\hline & & INDESIT & $10 V 75$ & \begin{tabular}{|l|} 
exaustắo \\
\end{tabular} & 69.00 & 6.00 & & & & & 94.00 & 85.54 & & 87.00 \\
\hline 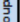 & & KUNFT & Kdm2739Av & exaustäo & 69.00 & 7.00 & & & & & 95.00 & 86.45 & & 94.00 \\
\hline & & BALAY & 3SB975B & exaustấo & 65.00 & 6.00 & & & & & 95.00 & 86.45 & & 90.00 \\
\hline & 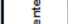 & WHIRLPOOL & DOLX70112 & ploondensaçẫo & 70.00 & 7.00 & & & & & 95.00 & 86.45 & & 95.00 \\
\hline & $\frac{2}{2}$ & ZANUSSI & ZDP7202PZ & ploondensaçẵo & 65.00 & 7.00 & & & & & 95.00 & 89.30 \& & & 94.00 \\
\hline & 襾 & ELECTROLU & EDP2074PDW & ploondensaçẵo & 64.00 & 7.00 & & & & & 95.00 & $89.30 \mathrm{~g}$ & & 93.00 \\
\hline 戛 & $\bar{\Omega}$ & $\begin{array}{l}\text { BOSCH } \\
\text { SMEG }\end{array}$ & $\begin{array}{l}\text { WTEE440707EE } \\
\text { DHT83LN }\end{array}$ & $\begin{array}{l}\text { Ploondensaçăo } \\
\text { Bombade Calor }\end{array}$ & $\begin{array}{l}64.00 \\
6500\end{array}$ & 5.000 & & & & & $\begin{array}{l}97.00 \\
89.00^{\circ}\end{array}$ & 91.18 & 83 & 99.00 \\
\hline & & $\begin{array}{l}\text { SMEG } \\
\text { ELECTROLU }\end{array}$ & $\begin{array}{l}\text { DHH83LLN } \\
\text { EDH3685TDW }\end{array}$ & $\begin{array}{l}\text { Bomba de Calor } \\
\text { Bomba de Calor }\end{array}$ & $\begin{array}{l}65.00 \\
66.00\end{array}$ & $\begin{array}{l}7.00 \\
6.00\end{array}$ & & & & & $\begin{array}{l}89.00 \\
95.00\end{array}$ & $89.30 \mathrm{~s}$ & & $\begin{array}{l}98.00 \\
9300\end{array}$ \\
\hline & & $\begin{array}{l}\text { ZANUSSI } \\
\text { ZANS }\end{array}$ & $\mathrm{ZOH} 8333 \mathrm{~W}$ & Bomba de Calor & $\begin{array}{l}63.00 \\
63.00\end{array}$ & $\begin{array}{l}6.00 \\
7.00\end{array}$ & & & & & $\begin{array}{l}95.00 \\
95.00\end{array}$ & $89.30 \mathrm{~s}$ & & 94.00 \\
\hline & & & Solução & & & & & Critério Social & ial|Conforto, & Gostos, Percep & pcões & & & 3.00 \\
\hline & & Marca & Modelo & & Ruido (dB) & $\begin{array}{l}\text { Vol. util( }\left(>-6^{\circ} \mathrm{C}\right) \\
\text { [I] }\end{array}$ & $\begin{array}{l}\text { Vol. util (k-6.6) } \\
\text { [1] }\end{array}$ & $\begin{array}{l}\text { Autonomia } \\
\text { Corte Energia } \\
\text { (horas) }\end{array}$ & & & $\begin{array}{c}\text { Qualidade } \\
\text { (Fiabilidade) }\end{array}$ & $\begin{array}{l}\text { Nr. } \\
\text { Funcionalidades }\end{array}$ & Design & $\begin{array}{l}\text { Assistencia Pos. } \\
\text { venda (Garantia) }\end{array}$ \\
\hline & \begin{tabular}{|l|l|} 
Sol.Ref. \\
\end{tabular} & WHIRLPOOL & ART867-G & & 43.00 & 203.00 & 102.00 & 4.00 & & & 92.00 & 189.24 & 54,00 & \\
\hline & & $\mid$ & $\begin{array}{l}\text { CFET 6 6184 XPU } \\
\end{array}$ & & 43.00 & 218.00 & 74.00 & 14.00 & & & 90.00 & 87.30 & 82.00 & \\
\hline & & CANDY & CFET 6182W & & 42.00 & 227.00 & 84.00 & 14.00 & & & 90.00 & 87.30 & 82.00 & 84 \\
\hline & & BECKEN & Bo2016 kx & & 43.00 & 222.00 & 95.00 & 14.00 & & & 99.00 & & 84.00 & 98 \\
\hline 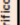 & 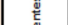 & & EN3390MOW & & 43.00 & 192.00 & 91.00 & 20.00 & & & 91.00 & 88.27 & 88.00 & 78 \\
\hline & & BALAY & $3 K S B 5410$ & & 39.00 & 194.00 & 94.00 & 19.00 & & & 95.00 & 92.15 & 86.00 & 90 \\
\hline 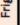 & 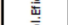 & BOSCH & KGV33VL31S & & 39.00 & 192.00 & 94.00 & 23.00 & & & 95.00 & 92.15 & 97.00 & 97 \\
\hline & $\bar{\Omega}$ & \begin{tabular}{|l|} 
INDESIT \\
HOOT
\end{tabular} & LI70FF1X & & 45.00 & 188.00 & 86.00 & 17.00 & & & 91.00 & & 83.00 & 87 \\
\hline & & HOOVER & HDCF 184 WDi1 & & $\begin{array}{l}43.00 \\
3900\end{array}$ & $\begin{array}{l}218.00 \\
1900\end{array}$ & 74.00 & 18.00 & & & 88.00 & 185.36 & 93.00 & 92 \\
\hline & & $\begin{array}{l}\text { SAMSUNNG } \\
\text { CANDY }\end{array}$ & $\begin{array}{l}\text { RBE2FFSNDDSA } \\
\text { CF 18S WIFU1 }\end{array}$ & & $\begin{array}{l}39.00 \\
43.00\end{array}$ & 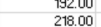 & $\begin{array}{l}98.00 \\
7400\end{array}$ & $\begin{array}{l}17.00 \\
14.00\end{array}$ & & & 95.00 & $\begin{array}{l}92.15 \\
87.30\end{array}$ & $\begin{array}{l}99.00 \\
9200\end{array}$ & 85 \\
\hline & & TANLYY & Soluçăo & & & & & Critério Social & ial/Conforto, & Gostos, Percep & g(çes) 90.00 & 87.30 & & \\
\hline & & Marca & Modelo & Tipo & & $\begin{array}{l}\text { Vol. util comp. } \\
\text { (II) }\end{array}$ & & & & & $\begin{array}{c}\text { Qualidade } \\
\text { (Fiabilidade) }\end{array}$ & $\begin{array}{c}\text { Nr. } \\
\text { Funcionalidades }\end{array}$ & Design & $\begin{array}{l}\text { Assistencia Pos. } \\
\text { venda (Garantia) }\end{array}$ \\
\hline & Sol.Ref. & Miele & H399B & & & 60 & & & & & & & 67 & \\
\hline & & $x$ & E2Z3430ADX & & & 60 & & & & & 87.30 & 89.92 & 86 & 83 \\
\hline & & $\begin{array}{lll}x \\
x\end{array}$ & EZC2430AOX & & & 57 & & & & & 87.30 & 89.92 & 66 & 83 \\
\hline$\frac{8}{5}$ & & $\mid \begin{array}{l}\text { BOSCH } \\
\text { HBA435360 }\end{array}$ & HBA43S360E & & & 61 & & & & & & & 70 & \\
\hline & हू & CATA & Cme $7007 X$ & & & 60 & & & & & & 90.92 & 88 & 78 \\
\hline & 焉 & Zanuss: & ZZB21601XV & & & 60 & & & & & 92.15 & 94.91 & 84 & 54 \\
\hline s. & $\frac{\pi}{8}$ & BOSCH & HEA21B250E & & & 61 & & & & & & & 70 & 85 \\
\hline & $\&$ & $\mathrm{BOSCH}$ & HBA42R350E & & & 61 & & & & & 88.27 & 90.92 & 70 & 97 \\
\hline & & BALAY & 3HB557XM & & & 60 & & & & & $85.36 \mathrm{~s}$ & 87.92 & 86 & 82 \\
\hline & & |SIEMENS & HB22AR521E & & & 61 & & & & & 94.72 & 97.56 & 83 & $82-2>$ \\
\hline & & SIEMENS & HB42AR555E & & & 61 & & & & & 89.73 & 92.42 & 83 & 82 \\
\hline & Soluçăo & & $\begin{array}{r}\text { Solução } \\
\end{array}$ & & & & & Critério Social & ial|Conforto, & Gostos, Percep, & prōes) & & & \\
\hline & & Marca & Modelo & & Ruido (dB) & $\begin{array}{l}\text { Capacidade } \\
\text { [servicos. } \\
\text { lousal }\end{array}$ & & & & & $\begin{array}{c}\text { Qualidade } \\
\text { (Fiabilidade) }\end{array}$ & $\begin{array}{l}\text { Nr. } \\
\text { Funcionalidades }\end{array}$ & Design & $\begin{array}{l}\text { Assistencia Pos. } \\
\text { venda (Garantia) }\end{array}$ \\
\hline & Sol.Ref. & ZANUSSI & DW683 & & 56.00 & 12.00 & & & & & 94.00 & 95.88 & 83 & 84.66 \\
\hline & & $\mathrm{BOSCH}$ & SMS46GW01E & & 46.00 & 12.00 & & & & & 97.00 & 98.94 & 85 & 86.7 \\
\hline 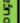 & & DAEWOO & DOW-MQ1214S & & 49.00 & 11.00 & & & & & 89.00 & 90.78 & 87 & 88.74 \\
\hline & & SIEMENS & iSensoric & & 48.00 & 12.00 & & & & & 95.00 & 96.9 & 96 & 97.92 \\
\hline & है & BOSCH & SMS25A100E & & 48.00 & 12.00 & & & & & 97.00 & 98.94 & 98 & 99.96 \\
\hline & & BOSCH & $\begin{array}{l}\text { SMS24AWO2E } \\
\text { POP }\end{array}$ & & 50.00 & 10.00 & & & & & 97.00 & 98.94 & 88 & 89.76 \\
\hline & $\frac{\overline{4}}{\overline{0}}$ & 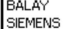 & $\begin{array}{l}\text { 3US30031P } \\
\text { iSensoric }\end{array}$ & & $\begin{array}{l}50.00 \\
46.00\end{array}$ & $\begin{array}{l}12.00 \\
1000\end{array}$ & & & & & $\begin{array}{l}96.00 \\
95.00\end{array}$ & $\begin{aligned} 97.92 \\
96.9\end{aligned}$ & $\begin{array}{l}98 \\
86\end{array}$ & $\begin{array}{l}99.96 \\
87.72\end{array}$ \\
\hline & $\&$ & $\begin{array}{l}\text { SIEMEANS } \\
\text { BALAY }\end{array}$ & $\begin{array}{l}\text { Siensoric } \\
\text { 3VS303BP }\end{array}$ & & $\begin{array}{l}46.00 \\
50.00\end{array}$ & $\begin{array}{l}10.00 \\
11.00\end{array}$ & & & & & 96.00 & $\begin{array}{r}96.9 \\
97.92\end{array}$ & 87 & 88.74 \\
\hline & & ELECTROLU & ESL7344RPO & & 46.00 & 12.00 & & & & & 96.00 & 97.92 & 89 & 90.78 \\
\hline & & $x$ & ESF5206LOX & & 49.00 & 12.00 & & & & & 96.00 & 97.92 & 89 & 90.78 \\
\hline
\end{tabular}

Figure A1. Cont. 


\begin{tabular}{|c|c|c|c|c|c|c|c|c|c|}
\hline & & & Solução & & & & Critério Amb & ental & \\
\hline & & Marca & Modelo/Ref: & Tipo & Emissōes $\mathrm{CO2}$ equiv. [v.anuais][kg] & Uso - Emissões COZe (horz.temp.)][kg] & Fabrico-Emissōes CO2e [kg] & & inal - Emissões CO2e [kg] \\
\hline & Sol.Ref. & Lexman & Ref: 3782637 & Halogenio & 14.51 & 145.07 & 23625 & 23625 & \\
\hline & & OSRAM & Ref: 3316242 & Halogenio & 25.44 & 254.42 & 23569 & 23569 & \\
\hline & & Phillips & Softone & Fluor. Compacta & 37.32 & 373.25 & 21025 & 21025 & \\
\hline & & Lexman & Ref: 3829536 & Led & 14.51 & 145.07 & 27589 & 27589 & \\
\hline 黑 & $\underset{\mathscr{W}}{\tilde{E}}$ & GE & EFL23W & Fluor. Compacta & 2340 & 234.01 & 21456 & 21456 & \\
\hline & $\frac{\underline{w}}{u}$ & LED & G45 & Led & 15.69 & 166.94 & 23466 & 23466 & \\
\hline & $\frac{\varrho}{\bar{\Psi}}$ & Phillips & ND7 & Led & 44.69 & 446.88 & 23488.5 & 23488.5 & \\
\hline & $\overline{\bar{\Omega}}$ & OSPAM & Facility & Fluorescente & 3873 & 381.27 & 23511 & 23511 & \\
\hline & & DESRAM & 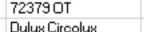 & $\begin{array}{l}\text { Fluor. Compacta } \\
\text { Fluoreseente }\end{array}$ & 2041 & $\begin{array}{l}204.12 \\
91271\end{array}$ & 23533.5 & 23533.5 & \\
\hline & & WIVA & OPAL & Led & 7312 & 731.19 & 23578.5 & 23578.5 & \\
\hline & & Marca & Modelo & Tipo & Emissỗes $C 02$ equiv. [v.anuais][k]] & Uso - Emissões COZe (horz.temp.).[kg] & Fabrico-Emissões CO2e [kg] & & inal - Emissões CO2e [kg] \\
\hline & Sol.Ref. & $\begin{array}{l}\text { GENERAL } \\
\text { ELECTRIC }\end{array}$ & AIR 112 & Spliter & 11.07 & 110.67 & 23625. & & 23625.00 \\
\hline & & SAMSUNG & AR12FSSYAWTN & MuliSpliter & & 0.00 & 23569.4 & & 23569.00 \\
\hline$\stackrel{\circ}{0}$ & & SAMSUNG & AQVOSPSEN & Mulis Spliter & 6.08 & 60.75 & 21025. & & 21025.00 \\
\hline & & OBERGOZO & FKDR 350 9KBTU & MultiSpliter & 6.28 & 62.78 & 27589. & & 27589.00 \\
\hline & & SAMSUNG & & MultiSpliter & 6.11 & 61.09 & 21456. & & 21456.00 \\
\hline & 递 & WHRLPOOL & PACW/9HP & Portatil & 5.58 & 55.77 & $23466 . \mathrm{C}$ & & 23466.00 \\
\hline & $\overline{\bar{n}}$ & & 9BTUSPM09SP 1X1 & 1 Spliter & 5.30 & 52.99 & 23488.5 & & 23488.50 \\
\hline & & HISENSE & AST- & Spliter & 4.83 & 48.26 & 23511. & & 23511.00 \\
\hline & & BECKEN & 9btus Bac23211k1 & Spliter & 5.03 & 50.29 & 23533. & & 23533.50 \\
\hline & & Inverter & Ase9uiEk & Spliter & 5.03 & 50.29 & 23556. & & 23556.00 \\
\hline & & MITSUEISHI & DXK0925 1X1 & Spliter & 1013 & 101.25 & 23578.5 & & 23578.50 \\
\hline & & Marca & Modelo & & Emissōes $\mathrm{CO} 2$ equiv. [v.anuais][ke] & Uso - Emissōes CO2e (horz.temp.)][kg] & Fabrico-Emissöes CO2e [k]] & & inal - Emissões CO2e [kg] \\
\hline & Sol.Ref. & IINDESIT & W152 & & 14,18 & 141.75 & 0.25 & 0.06 & \\
\hline & & WHIRLPOOL & AWOD053 & & 15.53 & 155.25 & 0.29 & 0.07 & \\
\hline & & WHIPLPOOL & FWG $71284 \mathrm{~W}$ & & 15.53 & 155.25 & 0.29 & 0.07 & \\
\hline & & zanussi & ZWF71050W & & 14.85 & 148.50 & 0.25 & 0.06 & \\
\hline & & SIEMENS & WI12A222ES & & 14.85 & 148.50 & 0.29 & 0.07 & \\
\hline & 递 & IINDESIT & EWE 71252 WEU/1 & & 1249 & 124.88 & 0.29 & 0.07 & \\
\hline & $\overline{\bar{g}}$ & KUNFT & $7 \mathrm{~kg}$ Kwm3485 & & 1249 & 124.88 & 0.25 & 0.06 & \\
\hline & & SAMSUNG & WW70.J5355MW & & 6.89 & 68.85 & 0.29 & 0.07 & \\
\hline$\Sigma$ & & AEG & L74272TL & & 6.89 & 68.85 & 0.29 & 0.07 & \\
\hline & & BECKEN & Bwm3215 & & 14.85 & 148.50 & 0.29 & 0.07 & \\
\hline & & HOTPOINT & FMG723MB & & 14.85 & 148.50 & 0.29 & 0.07 & \\
\hline & & & Solução & & & & Critério Amb & ental & \\
\hline & & Marca & Modelo & Tipo & Emissōes C02 equiv. [v.anuais][kg] & Uso - Emissões CO2e (horz,temp.)][kg] & Fabrico -Emissões CO2e [kg] & & inal-Emissões CO2e [kg] \\
\hline & Sol.Ret. & HOOVER & HNC 180 & ploondensaçăa & 3490 & 348.98 & 0.25 & 0.06 & \\
\hline & & INDESIT & IDV 75 & exaustẫo & 0.00 & 0.00 & 0.25 & 0.06 & \\
\hline & & KUNFT & $\mathrm{Kdm} 2739 \mathrm{Av}$ & exaustão & 17.55 & 175.50 & 0.29 & 0.07 & \\
\hline & & BALAY & $35 B 975 B$ & exaustão & 13.50 & 135.00 & 0.25 & 0.06 & \\
\hline & E & WHIPLPOOL & $\mathrm{DOL} \times 70112$ & plcondensą̧ã⿰o & 75 & 67.50 & 0.29 & 0.07 & \\
\hline & $\frac{\bar{\sigma}}{\frac{0}{9}}$ & zanussi & ZDP7202PZ & plcondensaçăo & 283 & 128.25 & 0.29 & 0.07 & \\
\hline & 苂 & ELECTROLU & EDP2074PDW & ploondensą̧ăo & 8.90 & 189.00 & 0.29 & 0.07 & \\
\hline & & $\mathrm{BOSCH}$ & WTE84107EE & ploondensação & 8.90 & 189.00 & 0.21 & 0.05 & \\
\hline & & SMEG & DHT83LIN & Bomba de Calor & 7.55 & 175.50 & 0.29 & 0.07 & \\
\hline & & ELECTROLU & EDH3685TDW & Bomba de Calor & 6.40 & 54.00 & 0.25 & 0.06 & \\
\hline & & zanussi & ZDH8333W & Bomba de Calor & 7.55 & 175.50 & 0.29 & 0.07 & \\
\hline & & & Soluçăo & & & & Critério Amb & ental & \\
\hline & & Marca & Modelo & & Emissōes C02 equiv. [v.anuais][kg] & Uso - Emissões CO2e (horz.temp.)][kg] & Fabrico - Emissões CO2e [kg] & & inal - Emissões CO2e [kg] \\
\hline & Sol.Ref. & WHIRLPOOL & ART867-G & & 168.75 & 1687.50 & 23625.00 & 23625.00 & \\
\hline & & CANOY & CFET 6184XPU & & 438.74 & 4387.43 & 23569.00 & 23569.00 & \\
\hline & & CANDY & CFET $6182 W$ & & 303.74 & 3037.43 & 21025.00 & 21025.00 & \\
\hline & & BECKEN & Bo2016 ls & & 269.99 & 2699.93 & 27589.00 & 27589.00 & \\
\hline$\frac{\underline{\underline{E}}}{\underline{\underline{E}}}$ & है & & EN3390MOW & & 474.52 & 4745.18 & 21456.00 & 21456.00 & \\
\hline & $\frac{\mathrm{g}}{\mathrm{v}}$ & BALAY & $3 K S B 5410$ & & 310.49 & 3104.93 & 23466.00 & 23466.00 & \\
\hline 患 & 产 & $\mathrm{BOSCH}$ & KGV33VL31S & & 370.57 & 3705.68 & 23488.50 & 23488.50 & \\
\hline & $\overline{\bar{a}}$ & | INDESIT & LI70FF1X & & 317.24 & 3172.43 & 23511.00 & 23511.00 & \\
\hline & & HOOVER & HDCF 184 WD/1 & & 398.24 & 3982.43 & 23533.50 & 23533.50 & \\
\hline & & SAMSUNG & RB29FSPRDSA & & 357.74 & 3577.43 & 23556.00 & 23556.00 & \\
\hline & & CANDY & CF 18 S WIFl1 & & 0624 & 5062.43 & 23578.50 & 23578.50 & \\
\hline & & & Solução & & & & Critério Amb & ental & \\
\hline & & Marca & Modelo & Tipo & Emissōes CO2 equiv. [v.anuais][kg] & Uso - Emissões COZe (horz.temp.).[kg] & Fabrico-Emissões CO2e [kg] & & inal-Emissōes CO2e [kg] \\
\hline & Sol.Ref. & Miele & H399B & & 209 & 20.93 & 23625.00 & 23625.00 & \\
\hline & & $x$ & EZB3430AOX & & 1.69 & 16.88 & 23569.00 & 23569.00 & \\
\hline & & & EZC2430AOX & & 1.70 & 16.98 & 21025.00 & 21025.00 & \\
\hline 粂 & & BOSCH & HRA435360E & & 228 & 2282 & 2758900 & 2758900 & \\
\hline & हू & $\left.\right|_{\text {CATA }} ^{\text {IEASSOU }}$ & Cme $7007 X$ & & 1.76 & 17.55 & 21456.00 & 21456.00 & \\
\hline & $\frac{\underline{\underline{g}}}{\underline{\underline{v}}}$ & ZANUSSI & ZZB21601XV & & 1.84 & 18.39 & 23466.00 & 23466.00 & \\
\hline & $\frac{\bar{t}}{\overline{0}}$ & $\mathrm{BOSCH}$ & HBA21B250E & & 1.67 & 16.74 & 23488.50 & 23488.50 & \\
\hline & $\overline{8}$ & $\mathrm{BOSCH}$ & HBA42R350E & & 2.42 & 24.17 & 23511.00 & 23511.00 & \\
\hline & & BALAY & 3HB557XM & & 2.16 & 21.60 & 23533.50 & 23533.50 & \\
\hline & & SIEMENS & HB22AR521E & & 1.89 & 18.90 & 23556.00 & 23556.00 & \\
\hline & & SIEMENS & HB42AR555E & & 242 & 24.17 & 23578.50 & 23578.50 & \\
\hline & Solução & & Soluç̃õo & & & & CritérioAmb & ental & \\
\hline & & Marca & Modelo & & Emissồes C02 equiv. [v.anuais][k]] & Uso - Emissões CO2e (horz.temp.).[kg] & Fabrico-Emissões CO2e [kg] & & inal - Emissöes CO2e [kg] \\
\hline & Sol.Ref. & ZANUSSI & DW683 & & 3490 & 348.98 & 23625.00 & 23625.00 & \\
\hline & & $\mathrm{BOSCH}$ & SMS46GW01E & & & 175.50 & 23569.00 & 23569.00 & \\
\hline 5 & & DAEWOO & DOW-MQ1214S & & 17.55 & 175.50 & 21025.00 & 21025.00 & \\
\hline & & SIEMENS & iSensoric & & 6.75 & 67.50 & 27589.00 & 27589.00 & \\
\hline & & $\mathrm{BOSCH}$ & SMS25AI00E & & 6.75 & 67.50 & 21456.00 & 21456.00 & \\
\hline & & $\mathrm{BOSCH}$ & SMS24AW02E & & 18.90 & 189.00 & 23466.00 & 23466.00 & \\
\hline$\frac{2}{3}$ & 递 & BALAY & 3VS3031P & & 18.90 & 189.00 & 23488.50 & 23488.50 & \\
\hline & $\overline{\bar{\Omega}}$ & SIEMENS & iSensoric & & 17.55 & 175.50 & 23511.00 & 23511.00 & \\
\hline & & BALAY & 3VS303BP & & 7.55 & 175.50 & 23533.50 & 23533.50 & \\
\hline & & ELECTROLU & ESL7344RO & & 7.55 & 175.50 & 23556.00 & 23556.00 & \\
\hline & & $x$ & ESF5206LOX & & & 175.50 & 23578.50 & 23578.50 & \\
\hline
\end{tabular}

Figure A1. Definition of the attribute table associated with the options available in the market, considered in this work. 


\section{Appendix B}

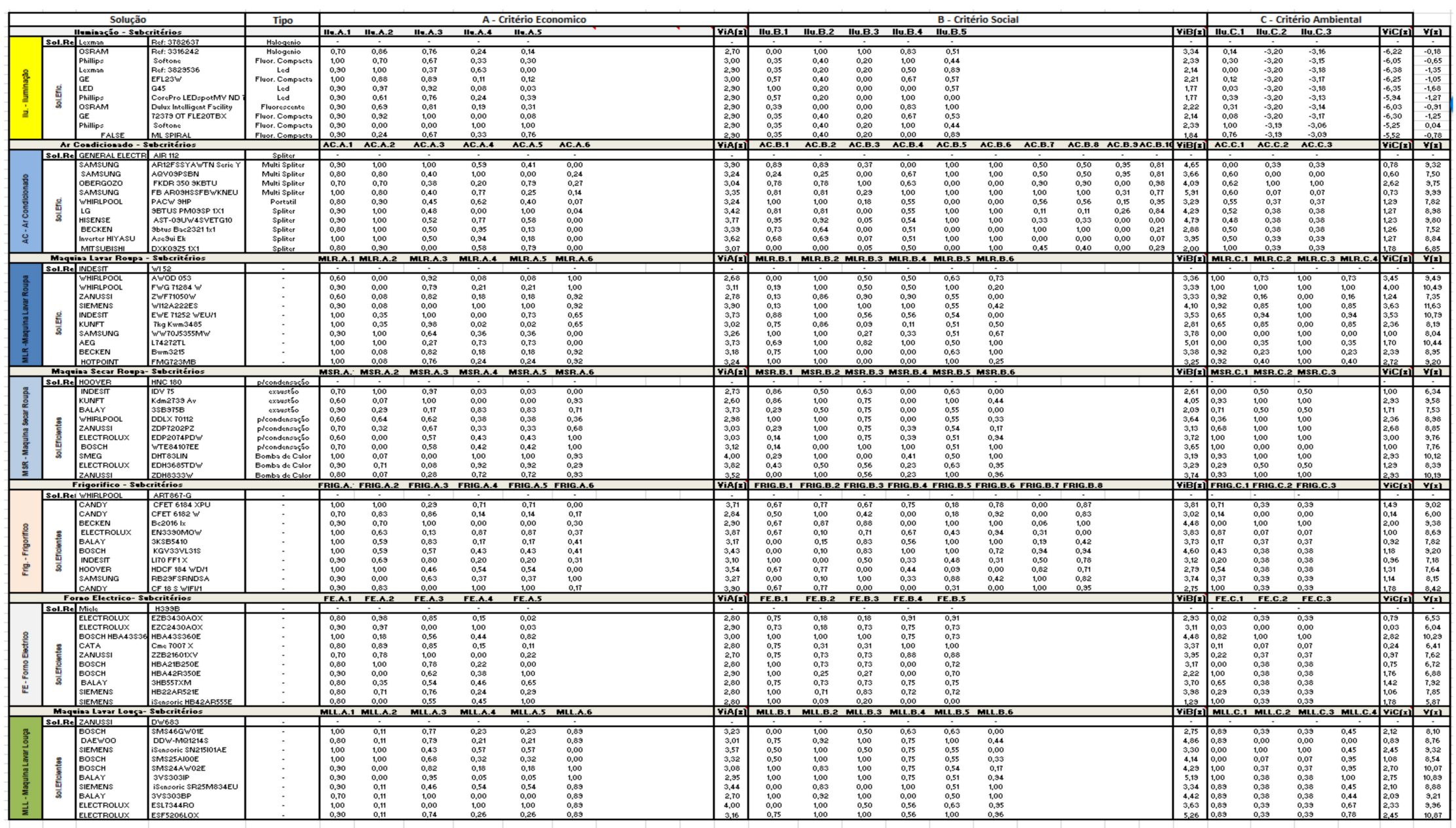

Figure A2. Definition of the table of values associated with the options available in the market that was considered in this work. 


\section{References}

1. IEA. Energy Efficiency 2019-Market Reports Series; OECD/IEA: Paris, France, 2019.

2. IPCC. Climate Change 2014: Mitigation of Climate Change Summary for Policymakers and Technical Summar; Intergovernmental Panel on Climate Change (IPCC): Geneva, Switzerland, 2015, ISBN 978-92-9169-142-5.

3. EC. 2020 Climate \& Energy Package. Available online: https://ec.europa.eu/clima/policies/strategies/2020_en (accessed on 28 March 2019).

4. Anastasiades, K.; Blom, J.; Buyle, M.; Audenaert, A. Translating the circular economy to bridge construction: Lessons learnt from a critical literature review. Renew. Sustain. Energy Rev. 2020, 117, 109522. [CrossRef]

5. EU. Climate and Energy Framework. Available online: https://www.consilium.europa.eu/en/policies/climatechange/2030-climate-and-energy-framework/ (accessed on 18 March 2019).

6. ADENE. Energy Labelling; ADENE: Lisbon, Portugal, 2017, ISBN 978-972-8646-36-3.

7. DGEG. Eficiência Energética em Edifícios_Programa E4; Direção Geral de Energia e Geologia: Lisboa, Portugal, 2012. (In Portuguese)

8. Wong, L.; Krüger, E. Comparing energy efficiency labelling systems in the EU and Brazil: Implications, challenges, barriers and opportunities. Energy Policy 2017, 109, 310-323. [CrossRef]

9. Mc Alister, C.; Green, S.; Fayole, C. Discussion Paper: Eco-Design as Part of Circular Economy_Implications for Market Surveillance; ECOS: Brussels, Belgium, 2018.

10. Corbett, J.; Wardle, K.; Chen, C. Toward a sustainable modern electricity grid: The effects of smart metering and program investments on demand-side management performance in the US electricity sector 2009-2012. IEEE Trans. Eng. Manag. 2018, 65, 252-263. [CrossRef]

11. Zapelloni, G.; Rellán, A.G.; Pastora, M.; Bugallo, B. Sustainable production of marine equipment in a circular economy: deepening in material and energy flows, best available techniques and toxicological impacts. Sci. Total Environ. 2019, 687, 991-1010. [CrossRef]

12. Schroeder, P.; Anggraeni, K.; Weber, U. The relevance of circular economy practices to the sustainable development goals. J. Ind. Ecol. 2019, 23, 77-95. [CrossRef]

13. Hao, S.; Kuah, A.T.; Rudd, C.D.; Wong, K.H.; Lai, N.Y.G.; Mao, J.; Liu, X. A circular economy approach togreen energy: Wind turbine, waste, and material recovery. Sci. Total Environ. 2020, 702, 135054. [CrossRef]

14. Tang, J.; Tong, M.; Sun, Y.; Du, J.; Liu, N. A spatio-temporal perspective of China's industrial circular economy development. Sci. Total Environ. 2019, 706, 135754. [CrossRef]

15. Fell, M. Energy services a conceptual review. Energy Res. Soc. Sci. 2017, 27, 129-140. [CrossRef]

16. Hoxha, E.; Jusselme, T. On the necessity of improving the environmental impacts of furniture and appliances in net-zero energy buildings. Sci. Total Environ. 2017, 596-597, 405-416. [CrossRef]

17. Ko, M.J.; Kim, Y.S.; Chung, M.H.; Jeon, H.C. Multi-objective design for a hybrid energy system using genetic algorithm. Energies 2015, 8, 2924-2949. [CrossRef]

18. Pombo, O.; Allacker, K.; Rivela, B.; Neila, J. Sustainability assessment of energy saving measures: A multi-criteria approach for residential buildings retrofitting a case study of the Spanish housing stock. Energy Build. 2016, 116, 384-394. [CrossRef]

19. Randall, M.; Rawlins, T.; Lewis, A.; Kipouros, T. Performance Comparison of Evolutionary Algorithms for Airfoil Design. Procedia Comput. Sci. 2015, 51, 2267-2276. [CrossRef]

20. Santos, R.; Abreu, A.; Matias, J.C.O. Energy Efficiency in buildings by using evolutionary algorithms: An approach to provide efficiency choices to the consumer, considering the rebound effect. In Proceedings of the Technological Innovation for Resilient Systems: 9th IFIP WG 5.5/SOCOLNET Advanced Doctoral Conference on Computing, Electrical and Industrial Systems, DoCEIS 2018, Costa de Caparica, Portugal, 2-4 May 2018; Springer: Basel, Switzerland, 2018. ISBN 978-3-319-78574-5.

21. Rubaiee, S.; Cinar, S.; Yildirim, M.B. An Energy-Aware Multiobjective Optimization Framework to Minimize Total Tardiness and Energy Cost on a Single-Machine Non preemptive Scheduling. IEEE Trans. Eng. Manag. 2018, 66, 699-714. [CrossRef]

22. Jafari, A.; Valentin, V. An optimization framework for building energy retrofits decision-making. Build. Environ. 2017, 115, 118-129. [CrossRef]

23. Chuah, J.W.; Raghunathan, A.; Jha, N.K. ROBESim: A retrofit oriented building energy simulator based on EnergyPlus. Energy Build. 2013, 66, 88-103. [CrossRef] 
24. Jain, A.S.; Saikia, P.; Rakshit, D. Thermal energy performance of an academic building with sustainable probing and optimization with evolutionary algorithm. Therm. Sci. Eng. Prog. 2020, 17, 100374. [CrossRef]

25. Mauro, G.M.; Hamdy, M.; Vanoli, G.P.; Bianco, N.; Hensen, J.L.M. A new methodology for investigating the cost-optimality of energy retrofitting a building category. Energy Build. 2015, 107, 456-478. [CrossRef]

26. Heo, Y.; Augenbroe, G.; Graziano, D.; Muehleisen, R.T.; Guzowski, L. Scalable methodology for large scale building energy improvement: Relevance of calibration in model-based retrofit analysis. Build. Environ. 2015, 87, 342-350. [CrossRef]

27. Le, K.N.; Tam, V.W.; Tran, C.N.; Wang, J.; Goggins, B. Life-Cycle Greenhouse Gas Emission Analyses for Green Star's Concrete Credits in Australia. IEEE Trans. Eng. Manag. 2019, 66, 286-298. [CrossRef]

28. Santos, R.S.; Matias, J.C.O.; Abreu, A.; Reis, F. Evolutionary algorithms on reducing energy consumption in buildings: An approach to provide smart and efficiency choices, considering the rebound effect. Comput. Ind. Eng. 2018, 126, 729-755. [CrossRef]

29. Santos, R.; Matias, J.C.O.; Abreu, A. A New Approach to Provide Sustainable Solutions for Residential Sector. IFIP Adv. Inf. Commun. Technol. 2019, 553, 329-342. [CrossRef]

(C) 2020 by the authors. Licensee MDPI, Basel, Switzerland. This article is an open access article distributed under the terms and conditions of the Creative Commons Attribution (CC BY) license (http://creativecommons.org/licenses/by/4.0/). 